\title{
Synthesis, Single Crystal Structural Investigation, Hirshfeld Surface Analysis, Thermoanalysis and Spectroscopic Study of Two New Cu(II) and Co(II) Transition-Metal Complexes
}

\author{
Rim Boubakri ${ }^{1}$, Mirosław Szybowicz ${ }^{2}{ }^{(D}$, Mariola Sadej ${ }^{3}{ }^{\circledR}$, Sarra Soudani ${ }^{1}$, Frédéric Lefebvre ${ }^{4} \mathbb{D}$, \\ Valeria Ferretti ${ }^{5}$, Cherif Ben Nasr ${ }^{1}$ and Kamel Kaabi ${ }^{1, *}$ \\ 1 Laboratoire de Chimie des Matériaux, Faculté des Sciences de Bizerte, Université de Carthage, Carthage 1054, \\ Tunisia; boubakri.rim@hotmail.fr (R.B.); sarrasoudani@yahoo.fr (S.S.); cherif_bennasr@yahoo.fr (C.B.N.) \\ 2 Faculty of Materials Engineering and Technical Physics, Instytut Badań Materiałowych i Inżynierii \\ Kwantowej/Institute of Materials Research and Quantum Engineering Piotrowo 3, 60-965 Poznan, Poland; \\ miroslaw.szybowicz@put.poznan.pl \\ 3 Faculty of Chemical Technology, Poznan University of Technology, Berdychowo 4, 60-965 Poznan, Poland; \\ mariola.sadej@put.poznan.pl \\ 4 Laboratoire de Chimie Organométallique de Surface (LCOMS), Ecole Supérieure de Chimie Physique \\ Electronique, CEDEX, 69626 Villeurbanne, France; lefebvre@cpe.fr \\ 5 Center for Structural Diffractometry, Department of Chemical and Pharmaceutical Sciences, Via Fossato di \\ Mortara 17, I-44121 Ferrara, Italy; valeria.ferretti@unife.it \\ * Correspondence: kamel_kaabi@yahoo.fr
}

\section{check for} updates

Citation: Boubakri, R.; Szybowicz, M.; Sadej, M.; Soudani, S.; Lefebvre, F.; Ferretti, V.; Ben Nasr, C.; Kaabi, K. Synthesis, Single Crystal Structural Investigation, Hirshfeld Surface Analysis, Thermoanalysis and Spectroscopic Study of Two New $\mathrm{Cu}(\mathrm{II})$ and $\mathrm{Co}(\mathrm{II})$ Transition-Metal Complexes. Crystals 2021, 11, 986. https://doi.org/10.3390/cryst11080986

Academic Editor: María Luz Durán

Received: 24 July 2021

Accepted: 15 August 2021

Published: 19 August 2021

Publisher's Note: MDPI stays neutral with regard to jurisdictional claims in published maps and institutional affiliations.

Copyright: (c) 2021 by the authors. Licensee MDPI, Basel, Switzerland. This article is an open access article distributed under the terms and conditions of the Creative Commons Attribution (CC BY) license (https:// creativecommons.org/licenses/by/ $4.0 /)$.
Abstract: Two new complexes, $\left[\mathrm{Cu}(\text { dimpyr })_{2}\left(\mathrm{H}_{2} \mathrm{O}\right)_{2}\right]\left(\mathrm{NO}_{3}\right)_{2} \cdot 2 \mathrm{H}_{2} \mathrm{O}(\underline{\mathbf{1}})$ and $(\mathrm{Hamdimpy})_{2}\left[\mathrm{CoCl}_{4}\right] \cdot \mathrm{H}_{2} \mathrm{O}$ (2), with the monodentate ligand 2-amino-6-methylpyrimidin-4-(1H)-one (dimpyr) and the countercation 4-amino-2,6-dimetylpyrimidium (Hamdimpy), respectively, were prepared and characterized by single crystal X-ray diffraction, elemental analysis and IR spectroscopy. In (1), the $\mathrm{Cu}(\mathrm{II})$ cation is tetracoordinated, in a square plan fashion, by two nitrogen atoms from the pyrimidine ring of the organic ligand and two oxygen atoms of two coordinated water molecules. In the atomic arrangement, the $\mathrm{CuO}_{2} \mathrm{~N}_{2}$ square planes are interconnected via the formation of $\mathrm{O}-\mathrm{H} \ldots \mathrm{O}$ hydrogen bonds involving both coordinated and free water molecules and $\mathrm{NO}_{3}{ }^{-}$nitrate anions to form inorganic layers parallel to the $(a, b)$ plane at $\mathrm{z}=(2 \mathrm{n}+1) / 4$. In (2), the central atom $\mathrm{Co}(\mathrm{II})$ is four-coordinated in a distorted tetrahedral fashion by four $\mathrm{Cl}^{-}$ions. The $\left[\mathrm{CoCl}_{4}\right]^{2-}$ tetrahedra are arranged parallel to the plane $(\overline{1} 10)$ at $x=(2 n+1) / 2$ and the organic cations are grafted between them by establishing with them hydrogen bonds of $\mathrm{CH} \ldots \mathrm{Cl}$ and $\mathrm{NH} \ldots \mathrm{Cl}$ types. The vibrational absorption bands were identified by infrared and Raman spectroscopy. Intermolecular interactions were investigated via Hirshfeld surfaces and electronic properties such as HOMO and LUMO energies were derived. The two compounds were characterized by thermal analysis to determine their thermal behavior with respect to temperature.

Keywords: coordination compound; X-ray structure; Hirshfeld surface; DFT calculations; DTA-TGA

\section{Introduction}

Synthesis and characterization of such complexes of the first-row transition metals including copper and cobalt have received large attention in recent times due to their wide variety of topologies and structural diversity and their potential applications as functional materials, such as gas storage, ion exchange, catalysis, magnetism, nonlinear optical response, and the development of new pharmaceutical drugs, etc. [1-4]. Copper complexes containing heterocyclic organic ligands, such as pyrimidine, have shown a wide range of biological and pharmaceutical activities that include DNA binding and cleavage, antimicrobial, anticancer and antioxidant behavior [5-8]. The complexes of Cobalt can control the activity of organic drugs and also can be used as contrast agents 
in MRI (magnetic resonance imaging) because of the magnetic function of $\mathrm{Co}$ (II) and Co(III) [9]. They also have interesting applications in homogeneous catalysis [10]. Cobalt is an essential trace element found in all animals and employed as a cofactor of vitamin B12; consequently, it can regulate the synthesis of DNA and maintain the normal functioning of the nervous system and brain [11].

Pyrimidines are heterocyclic aromatic compounds similar to pyridines containing two nitrogen atoms. They are of extreme importance given that three of the four nucleic bases in DNA, cytosine, thymine and uracil are derivatives of pyrimidine. Thus, pyrimidines and related compounds have received enormous attention, both for their role in vivo in biological systems and for their chemical and physical properties. Like pyridine and its derivatives, pyrimidines are also ideal as ligands for the formation of coordination complexes with virtually any type of metal cation.

The three-dimensional Hirshfeld surface and the corresponding two-dimensional fingerprint map are unique for each molecule/ion constituting the asymmetric unit of a crystal structure. They provide an easy way of comparing intermolecular contacts relative to van der Waals radii through a simple red-white-blue colour scheme [12].

The density functional theory (DFT)-derived theoretical quantum calculations have been successfully employed in many fields of science [13-17]. Analysis of spectroscopic and quantum calculations is found to be very important to envisage various quantum chemical parameters [18-22].

In continuation of our previous work, a successful attempt investigates structural parameters such as total energy, electron density in highest occupied molecular orbital (HOMO) and lowest unoccupied molecular orbital (LUMO), Mulliken charge and spectroscopic characterization of two new complexes of copper and cobalt $\left[\mathrm{Cu}(\operatorname{dimpyr})_{2}\left(\mathrm{H}_{2} \mathrm{O}\right)_{2}\right]$ $\left(\mathrm{NO}_{3}\right)_{2} \cdot 2 \mathrm{H}_{2} \mathrm{O}(\mathbf{1})$ and (Hamdimpy) $)_{2}\left[\mathrm{CoCl}_{4}\right] \cdot \mathrm{H}_{2} \mathrm{O}(\mathbf{2})$. One of our main objectives is to perform density functional theory (DFT) calculations on these systems to evaluate their accuracy against the obtained experimental results.

\section{Materials and Methods}

\subsection{Chemical Preparation}

2.1.1. Preparation of $\left[\mathrm{Cu}(\text { dimpyr })_{2}\left(\mathrm{H}_{2} \mathrm{O}\right)_{2}\right]\left(\mathrm{NO}_{3}\right)_{2} \cdot 2 \mathrm{H}_{2} \mathrm{O}(\underline{\mathbf{1}})$

The synthesis of $\left[\mathrm{Cu}(\text { dimpyr })_{2}\left(\mathrm{H}_{2} \mathrm{O}\right)_{2}\right]\left(\mathrm{NO}_{3}\right)_{2} \cdot 2 \mathrm{H}_{2} \mathrm{O}$ was carried out by addition of a solution of 2-amino-6-methylpyrimidin-4-ol $(0.4 \mathrm{mmol})$ in ethanol $(10 \mathrm{~mL})$ to $10 \mathrm{~mL}$ of an aqueous solution of $\mathrm{CuNO}_{3} \cdot 6 \mathrm{H}_{2} \mathrm{O}(0.2 \mathrm{mmol})$. The mixture was then stirred for $40 \mathrm{~min}$ at room temperature. The resulting solution was filtered and the filtrate was kept at room temperature for slow evaporation. After a few days, dark blue crystals suitable for X-ray diffraction were obtained (yield 58\%). Anal. Calc.: C, 14.18; H, 4.73; N, 16.54. Found: C, $14.42 ; \mathrm{H}, 4.39 ; \mathrm{N}, 16.82 \%$.

\subsubsection{Preparation of (Hamdimpy) ${ }_{2}\left[\mathrm{CoCl}_{4}\right] \cdot \mathrm{H}_{2} \mathrm{O}(\underline{2})$}

The synthesis of (Hamdimpy) $)_{2}\left[\mathrm{CoCl}_{4}\right] \cdot \mathrm{H}_{2} \mathrm{O}(\underline{2})$ was carried out by addition of a solution of hydrochloric acid $(28.70 \mathrm{mg}, 0.2 \mathrm{mmol})$ in water $(5 \mathrm{~mL})$ to a solution of 4 amino-2,6-dimethylpyrimidine $(20.63 \mathrm{mg}, 0.2 \mathrm{mmol})$ in ethanol $(10 \mathrm{~mL})$. Then, $10 \mathrm{~mL}$ of an aqueous solution of cobalt chloride $(27.2 \mathrm{mg}, 0.2 \mathrm{mmol})$ was added, drop by drop, to this mixture. After stirring for $40 \mathrm{~min}$, the mixture was filtered. Colorless crystals suitable for X-ray analysis were obtained after five days by slow evaporation of the filtrate at room temperature (yield 65\%.) Anal. Calc.: C, 14.12; H, 4.11; N, 12.53. Found: C, 14.53; H, 4.26; $\mathrm{N}, 12.32 \%$.

\subsection{X-ray Diffraction Study}

The crystallographic data for the $\mathrm{Cu}$ and Co complexes were collected on a Nonius Kappa CCD diffractometer at room temperature using graphite-monochromated $\mathrm{MoK} \alpha$ radiation $(\lambda=0.71073 \AA)$ with a $\varphi$ scan followed by $\omega$ scan to fill the sphere. Data sets were integrated with the Denzo-SMN package [23] and corrected for Lorenz, polarization 
and absorption effects [24]. The structures were solved by direct methods with the SIR97 program [25] and refined on $F^{2}$ by full-matrix least-squares methods with anisotropic non$\mathrm{H}$ atoms. Hydrogens linked to $\mathrm{C}$ atoms were included on calculated positions, riding on their carrier atoms, while those of the $\mathrm{NH}_{2} / \mathrm{NH}$ groups and water molecules were located in difference Fourier maps and refined isotropically. All calculations were performed using SHELXL-2014/7 [26] implemented in the WINGX system of programs [27]. Data collection parameters are listed in Table 1. Selected bond distances and angles are given in Table 2 and hydrogen bonding geometrical parameters in Table 3.

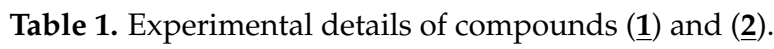

(1) (2)

\begin{tabular}{|c|c|c|}
\hline \multicolumn{3}{|l|}{ Crystal Data } \\
\hline Chemical formula & {$\left[\mathrm{Cu}\left(\mathrm{C}_{6} \mathrm{H}_{8} \mathrm{~N}_{2} \mathrm{O}\right)_{2}\left(\mathrm{H}_{2} \mathrm{O}\right)_{2}\right]\left(\mathrm{NO}_{3}\right)_{2} \cdot 2 \mathrm{H}_{2} \mathrm{O}$} & $\left(\mathrm{C}_{6} \mathrm{H}_{10} \mathrm{~N}_{3}\right)_{2}\left[\mathrm{CoCl}_{4}\right] \cdot \mathrm{H}_{2} \mathrm{O}$ \\
\hline$M_{\mathrm{r}}$ & 507.91 & 467.08 \\
\hline Crystal system, space group & Monoclinic, $C 2 / c$ & Triclinic, $\mathrm{P} \overline{1}$ \\
\hline Temperature $(\mathrm{K})$ & 295 & 295 \\
\hline$a, b, c(\AA)$ & $15.7637(5), 13.2632(6), 10.7707(4)$ & 7.9579 (3), $9.5893(3), 14.7692(4)$ \\
\hline$\alpha, \beta, \gamma\left({ }^{\circ}\right)$ & $90,104.185(2), 90$ & $98.820(2), 105.398(2), 105.6600(19)$ \\
\hline$V\left(\AA^{3}\right)$ & $2183.24(15)$ & $1015.06(6)$ \\
\hline Z & 4 & 2 \\
\hline Radiation type & Mo $K \alpha$ & Mo $K \alpha$ \\
\hline$\mu\left(\mathrm{mm}^{-1}\right)$ & 1.07 & 1.38 \\
\hline Crystal size $(\mathrm{mm})$ & $0.23 \times 0.16 \times 0.12$ & $0.47 \times 0.23 \times 0.15$ \\
\hline \multicolumn{3}{|l|}{ Data collection } \\
\hline Diffractometer & Nonius Kappa CCD & Nonius Kappa CCD \\
\hline Absorption correction & Multi-scan & Multi-scan \\
\hline$T_{\min }, T_{\max }$ & $0.759,0.860$ & $0.612,0.832$ \\
\hline $\begin{array}{l}\text { No. of measured, independent and } \\
\text { observed }[I>2 \sigma(I)] \text { reflections }\end{array}$ & $12,522,3187,2231$ & $13,967,4362,3804$ \\
\hline$R_{\text {int }}$ & 0.045 & 0.070 \\
\hline$(\sin \theta / \lambda)_{\max }\left(\AA^{-1}\right)$ & 0.704 & 0.639 \\
\hline \multicolumn{3}{|l|}{ Refinement } \\
\hline$R\left[F^{2}>2 \sigma\left(F^{2}\right)\right], w R\left(F^{2}\right), S$ & $0.044,0.136,1.03$ & $0.050,0.148,1.06$ \\
\hline No. of reflections & 3187 & 4362 \\
\hline No. of parameters & 163 & 249 \\
\hline No. of restraints & 5 & 3 \\
\hline$\Delta \rho_{\max }, \Delta \rho_{\min }\left(\mathrm{e} \AA^{-3}\right)$ & $0.42,-0.46$ & $0.94,-0.61$ \\
\hline
\end{tabular}

Table 2. Selected bond distances and angles $\left(\AA{ }^{\circ},{ }^{\circ}\right.$ in complex $(\underline{\mathbf{1}})$.

\begin{tabular}{cccc}
\hline Cu1-O2W & $1.924(2)$ & O2W-Cu1-O1W & 180.0 \\
Cu1-O1W & $1.936(3)$ & O2W-Cu1-N1 & $89.48(5)$ \\
Cu1-N1 & $1.970(2)$ & O1W-Cu1-N1 & $90.52(5)$ \\
N1-C1 & $1.312(3)$ & O1-C4-N1 & $116.0(2)$ \\
N1-C4 & $1.386(3)$ & $\mathrm{C} 1-\mathrm{N} 1-\mathrm{C} 4$ & $121.5(2)$ \\
$\mathrm{N} 2-\mathrm{C} 1$ & $1.337(3)$ & $\mathrm{C} 1-\mathrm{N} 2-\mathrm{C} 2$ & $121.7(2)$ \\
$\mathrm{N} 2-\mathrm{C} 2$ & $1.372(3)$ & $\mathrm{N} 1-\mathrm{C} 1-\mathrm{N} 2$ & $121.0(2)$ \\
$\mathrm{O} 1-\mathrm{C} 4$ & $1.244(3)$ & $\mathrm{O} 1-\mathrm{C} 4-\mathrm{C} 3$ & $127.2(2)$ \\
$\mathrm{C} 1-\mathrm{C} 5$ & $1.484(3)$ & $\mathrm{N} 1-\mathrm{C} 4-\mathrm{C} 3$ & $116.8(2)$ \\
$\mathrm{C} 2-\mathrm{C} 3$ & $1.347(4)$ & $\mathrm{N} 1-\mathrm{C} 1-\mathrm{C} 5$ & $119.6(2)$ \\
$\mathrm{C} 2-\mathrm{C} 6$ & $1.501(3)$ & $\mathrm{N} 2-\mathrm{C} 1-\mathrm{C} 5$ & $119.4(2)$ \\
$\mathrm{C} 3-\mathrm{C} 4$ & $1.427(4)$ & $\mathrm{C} 3-\mathrm{C} 2-\mathrm{N} 2$ & $118.6(2)$ \\
& & $\mathrm{C} 3-\mathrm{C} 2-\mathrm{C} 6$ & $125.5(3)$ \\
& & $\mathrm{N} 2-\mathrm{C} 2-\mathrm{C} 6$ & $115.9(3)$ \\
& & $\mathrm{C} 2-\mathrm{C} 3-\mathrm{C} 4$ & $120.3(2)$ \\
\hline
\end{tabular}


Table 3. Hydrogen bonding parameters $\left(\AA{ }^{\circ}{ }^{\circ}\right)$ in complex $(\underline{\mathbf{1}})$.

\begin{tabular}{|c|c|c|c|c|}
\hline D-H ...A & D-H & $\mathbf{D} \ldots \mathrm{A}$ & $\mathbf{H} \ldots \mathrm{A}$ & D-H ...A \\
\hline O1W-H . . O3 & $0.82(3)$ & $2.775(3)$ & $2.00(3)$ & $155(3)$ \\
\hline O3W-H . . O 1 & $0.86(3)$ & $2.725(3)$ & $1.87(2)$ & $173(2)$ \\
\hline $\mathrm{N} 2-\mathrm{H} \ldots \mathrm{O} 2^{\mathrm{i}}$ & $0.86(3)$ & $2.828(3)$ & $1.98(3)$ & $166(3)$ \\
\hline C6-H .. O $4{ }^{\mathrm{ii}}$ & 0.96 & $3.357(4)$ & 2.54 & 141 \\
\hline $\mathrm{O} 3 \mathrm{~W}-\mathrm{H} \ldots \mathrm{O} 2{ }^{\mathrm{iii}}$ & $0.81(2)$ & $2.821(3)$ & $2.04(2)$ & $160(3)$ \\
\hline $\mathrm{O} 2 \mathrm{~W}-\mathrm{H}_{\text {iv }}^{\mathrm{H}} . \mathrm{O} 3 \mathrm{~W}$ & $0.83(3)$ & $2.634(3)$ & $1.80(3)$ & $173(3)$ \\
\hline
\end{tabular}

Symmetry code: (i) $1 / 2-x, 1 / 2-y,-z$; (ii) $x+1 / 2,1 / 2-y, z+1 / 2$; (iii) $1 / 2-x, 1 / 2-y, 1-z$; and (iv) $-x$, $-\mathrm{y}, 1-\mathrm{z}$.

CCDC 1982375 and 1982385 contain the supplementary crystallographic data for the $\mathrm{Cu}$ and Co complexes, respectively. These data can be obtained free of charge from The Cambridge Crystallographic Data Centre via www.ccdc.cam.ac.uk/structures (accessed on 10 August 2021).

\subsection{DFT Calculations}

For compound ( $\underline{\mathbf{1}})$, calculations were made on the copper (II) complex using the B3LYP / 6-31+G* method for all atoms, including copper. In a first step, the positions of the hydrogen atoms were optimized with the B3LYP/6-31+G* method and the various properties were calculated on this optimized structure.

For compound (2), calculations were made on a system comprising the two organic molecules and the water molecule in order to take into account the interactions between the aromatic rings. All the calculations were made with the B3LYP/6-31+ $\mathrm{G}^{*}$ method and the positions of the protons were previously optimized with the same method. For the calculations of the infrared and Raman spectra, the contribution of the $\left[\mathrm{CoCl}_{4}\right]^{2-}$ complex in compound (2) calculated under the same conditions (B3LYP/6-31+ $\mathrm{G}^{*}$ ) has been added.

\subsection{IR Measurements}

The Fourier transform infrared spectroscopy (FT-IR) spectra were recorded using a Nicole Impact 410 FT-IR spectrophotometer in the range $4000-400 \mathrm{~cm}^{-1}$.

\subsection{Raman Spectroscopy}

Nonpolarized Raman spectra were recorded in the spectral range of $100-3200 \mathrm{~cm}^{-1}$, in the backscattering geometry, using the confocal in Via Renishaw micro-Raman system. Excitation light of $488 \mathrm{~nm}$ from a tunable Ar-ion laser was used. A Leica50x long working distance microscope objective (LWD) with a numerical aperture (NA) of 0.5 enabled the focusing of the laser beam to a diameter of approx. $2 \mu \mathrm{m}$ on the sample surface. During measurements, the excitation of the laser power was fixed at approximately $5 \mathrm{~mW}$ to minimize sample degradation or sample heating. Both data collection and deconvolution of the obtained spectra using the curve fitting method were performed using Renishaw WiRE 3.4 (Reinshaw) software.

\subsection{Thermal Properties}

Thermal analysis by differential scanning calorimetry was performed using a Mettler Toledo apparatus (DSC1 Mettler Toledo). All samples (about $10 \mathrm{mg}$ ) were heated from -80 to $300{ }^{\circ} \mathrm{C}$ with a heating rate of $10^{\circ} \mathrm{C} \cdot \mathrm{min}^{-1}$ under nitrogen atmosphere. Thermal values were evaluated from the first run of DSC measurements.

The thermal resistance was investigated with a TG 209 F3 Tarsus thermogravimetric analyzer (NETZSCH-Geratebau GmbH, Münster, Germany). Samples of $10 \mathrm{mg}$ each were heated in $\mathrm{Al}_{2} \mathrm{O}_{3}$ crucibles from 40 to $700{ }^{\circ} \mathrm{C}$ at a scan rate of $10^{\circ} \mathrm{C} \cdot \mathrm{min}^{-1}$ under nitrogen atmosphere (purge of $20 \mathrm{~mL} / \mathrm{min}$ of $\mathrm{N}_{2}$ protection gas and $30 \mathrm{~mL} \cdot \mathrm{min}^{-1}$ of $\mathrm{N}_{2}$ sample gas). 
The decomposition temperature material was determined at 10 and $50 \%$ weight loss. The residual mass $(\mathrm{R})$ was defined at about $\sim 600^{\circ} \mathrm{C}$.

\section{Results and Discussion}

\subsection{Structure Description}

\subsubsection{Structure Description of $\left[\mathrm{Cu}(\text { dimpyr })_{2}\left(\mathrm{H}_{2} \mathrm{O}\right)_{2}\right]\left(\mathrm{NO}_{3}\right)_{2} \cdot 2 \mathrm{H}_{2} \mathrm{O}(\underline{\mathbf{1}})$}

Since the metal atom and the coordinated water molecules reside on a twofold axis, the asymmetric unit consists of one half $\left[\mathrm{Cu}(2,6 \text {-dimethylpyrimidine-4- }(1 \mathrm{H}) \text {-one })_{2}\left(\mathrm{H}_{2} \mathrm{O}\right)_{2}\right]^{2+}$ cation, one nitrate anion and one cocrystallized water molecule (Figure 1). The $\mathrm{Cu}(\mathrm{II})$ metal atom is four-coordinated by the two nitrogen atoms $\mathrm{N} 1$ and $\mathrm{N} 1^{\mathrm{i}}(\mathrm{i}:-\mathrm{x}, \mathrm{y},-\mathrm{z}+1 / 2)$ of the organic ligands and the two oxygen atoms of the coordinated water molecules; the values of the cis angles around the $\mathrm{Cu}$ atom, reported in Table 2, show a slight distortion from the ideal square plane geometry. The $\mathrm{Cu}-\mathrm{Ow}$ and $\mathrm{Cu}-\mathrm{N} 1$ bond distances are comparable to those observed in other complexes of $\mathrm{Cu}(\mathrm{II})$ with pyrimidine derivatives [28,29].

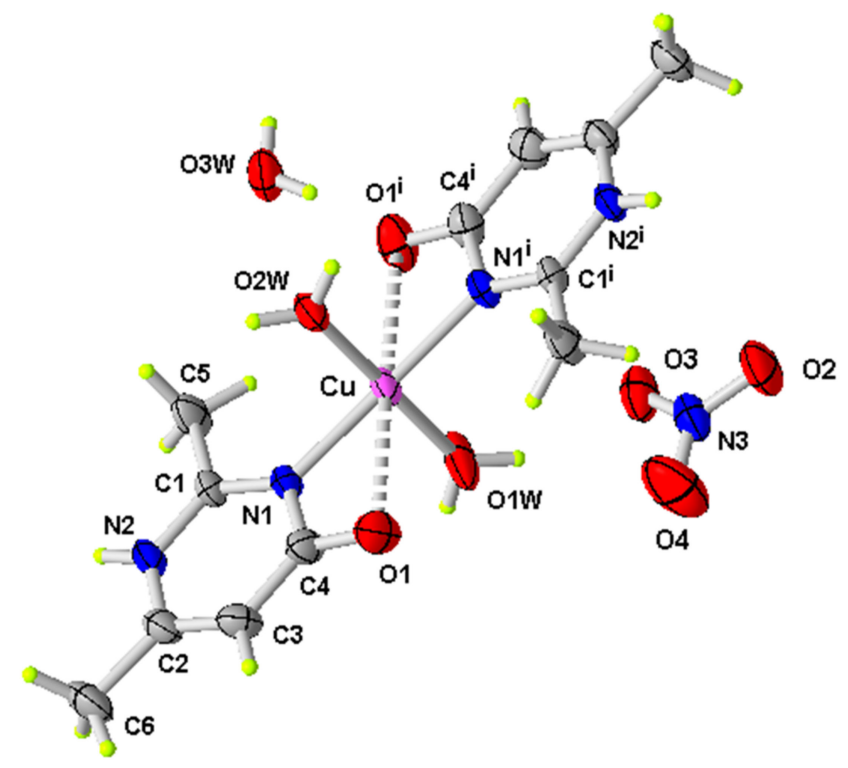

Figure 1. ORTEP of the structure of $(\underline{\mathbf{1}})$ with displacement ellipsoids drawn at the $50 \%$ probability level (i: $-x, y,-z+1 / 2)$.

Moreover, the quinone groups of the coordinated organic ligands are in close contact to the central atom at a $\mathrm{Cu}$... O distance of $2.666 \AA$. The C4-O1 bond distance [1.244 (5) $\AA$ ] is typical of a double bond and proves the presence of the keto form of the keto-enol tautomeric equilibrium (Scheme 1):<smiles>Cc1cc(O)nc(N)n1</smiles>

Scheme 1. Keto-enol equilibrium of the organic ligand.

The structural parameters of the pyrimidine derivative, listed in Table 2, agree with values usually found in the literature $[19,20]$.

In the crystal arrangement, the inorganic parts are interconnected by the formation of $\mathrm{O}-\mathrm{H}$... O hydrogen bonds involving both coordinated and free water molecules and $\mathrm{NO}_{3}{ }^{-}$nitrate anions, which form cyclic patterns that can be described, according to the graph set analysis, as $\mathrm{R}_{2}^{2}(32)$ rings, (Figure 2). 


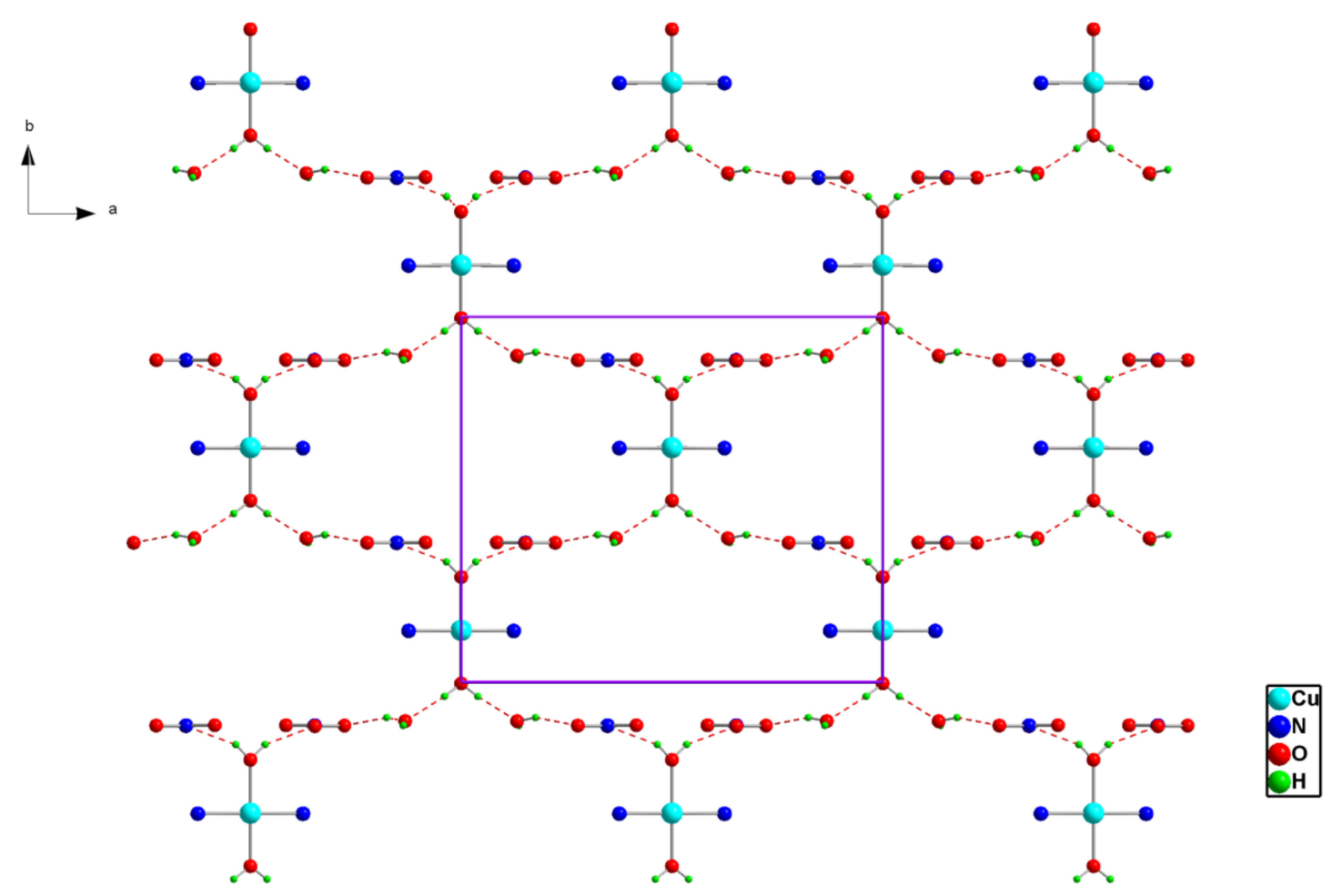

Figure 2. Projection of an inorganic layer in ( $\underline{\mathbf{1}})$ along the c-axis. Dotted lines indicate hydrogen bonds.

The inorganic layers are parallel to the $(a, b)$ plane at $\mathrm{z}=(2 \mathrm{n}+1) / 4$ (Figure 2), while the organic moieties are arranged perpendicularly to it, creating pores extending along the axis a and located at $(0, n / 4, n / 2)$ (Figure 3). Thus, this organic-inorganic hybrid material could have potential applications as a molecular sieve. The different components of the title material are interconnected together by three types of hydrogen bonds, $\mathrm{O}-\mathrm{H} \ldots \mathrm{O}$, $\mathrm{N}-\mathrm{H} \ldots \mathrm{O}$ and $\mathrm{C}-\mathrm{H} \ldots \mathrm{O}$ (Table 3), to form a three-dimensional network.

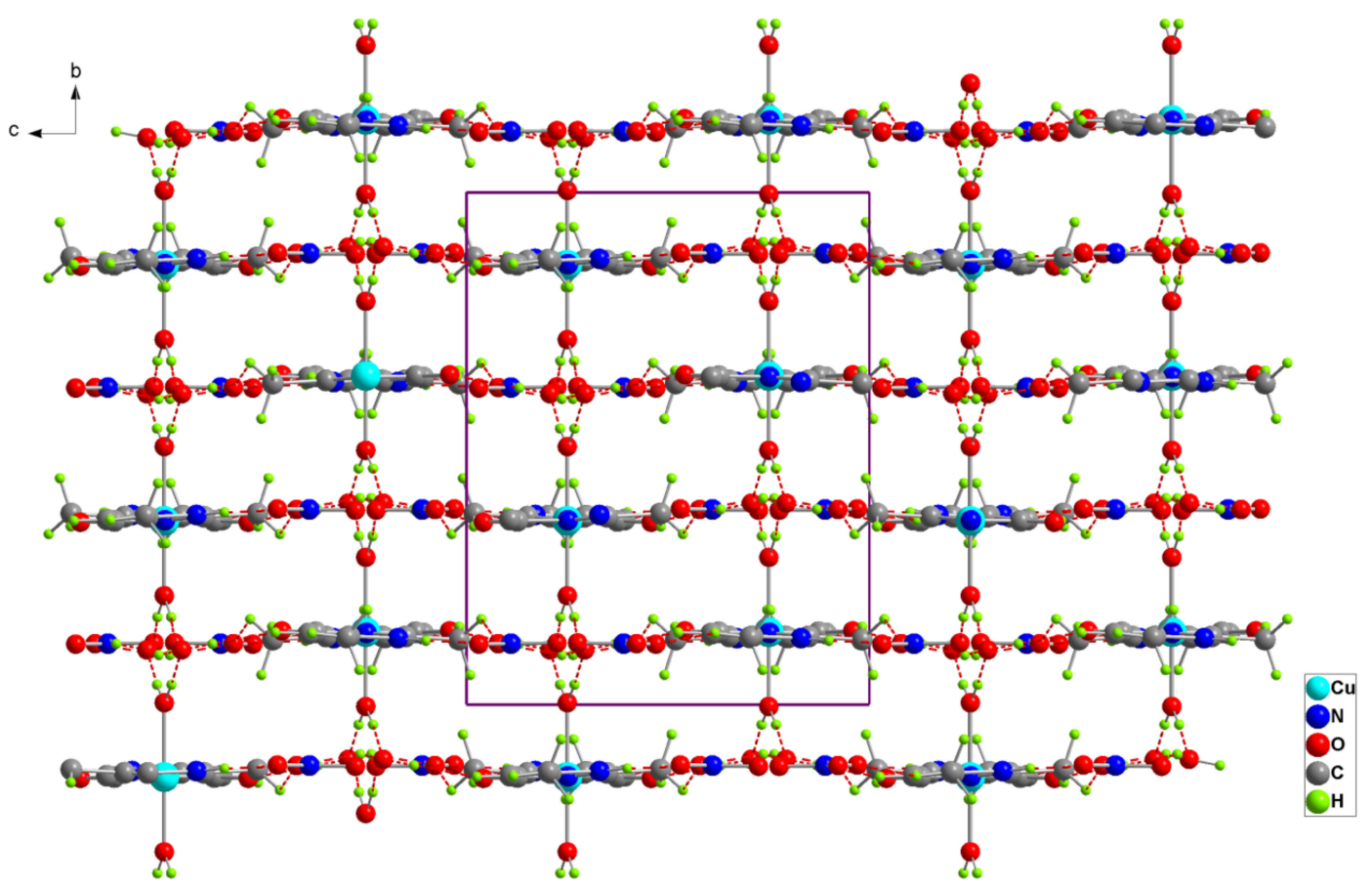

Figure 3. Projection of the structure of $(\underline{\mathbf{1}})$ along the a-axis. Dotted lines indicate hydrogen bonds. 


\subsubsection{Structure Description of (Hamdimpy) ${ }_{2}\left[\mathrm{CoCl}_{4}\right] \cdot \mathrm{H}_{2} \mathrm{O}(\underline{\mathbf{2}})$}

The asymmetric unit of (2) consists of one tetrachlorocobaltate(II) $\left[\mathrm{CoCl}_{4}\right]^{2-}$ ion, one interstitial water molecule and two 2-amino-4,6-dimethylpyrimidine molecules (Figure 4). The central atom $\mathrm{Co}$ (II) is coordinated to four $\mathrm{Cl}^{-}$ions. The detailed geometry of the $\mathrm{CoCl}_{4}$ anion is listed in Table 4.

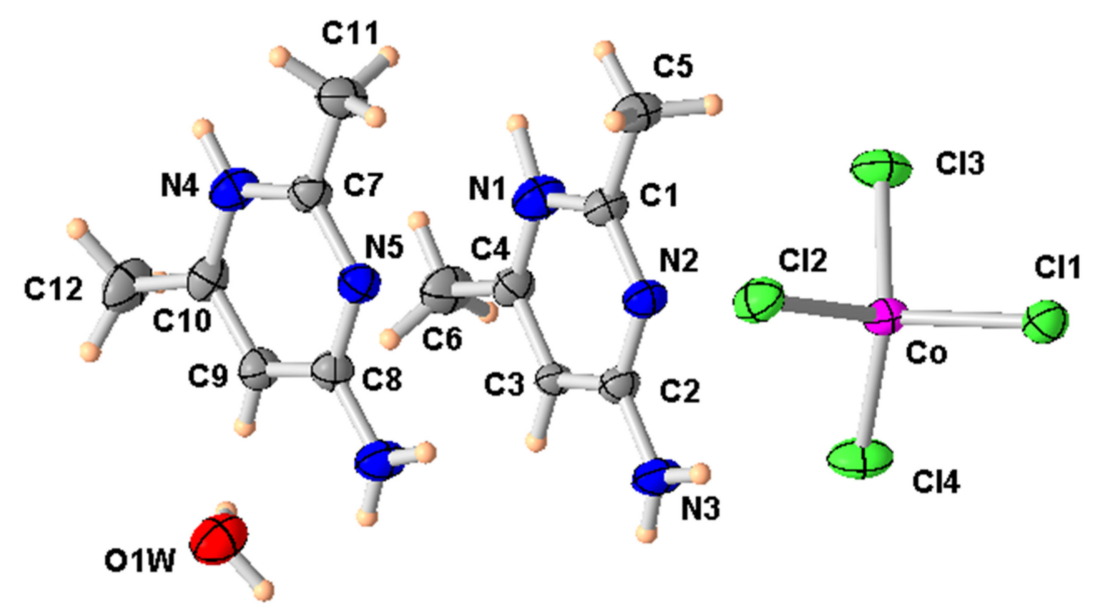

Figure 4. ORTEP of the structure of (2) with displacement ellipsoids drawn at the $50 \%$ probability level.

Table 4. Selected bond distances and angles $\left(\AA^{,}{ }^{\circ}\right)$ in complex (2).

\begin{tabular}{|c|c|c|c|}
\hline $\mathrm{Co} 1-\mathrm{Cl} 4$ & $2.2437(8)$ & $\mathrm{Cl} 4-\mathrm{Co} 1-\mathrm{Cl} 1$ & $110.97(3)$ \\
\hline Co1-Cl1 & $2.2719(7)$ & $\mathrm{Cl} 4-\mathrm{Co} 1-\mathrm{Cl} 3$ & $109.39(3)$ \\
\hline $\mathrm{Co} 1-\mathrm{Cl} 3$ & $2.2783(8)$ & $\mathrm{Cl} 1-\mathrm{Co} 1-\mathrm{Cl} 3$ & $107.12(3)$ \\
\hline $\mathrm{Co} 1-\mathrm{Cl} 2$ & $2.2843(8)$ & $\mathrm{Cl} 4-\mathrm{Co} 1-\mathrm{Cl} 2$ & $112.39(4)$ \\
\hline $\mathrm{N} 1-\mathrm{C} 4$ & $1.368(4)$ & $\mathrm{Cl} 1-\mathrm{Co} 1-\mathrm{Cl} 2$ & $109.06(3)$ \\
\hline $\mathrm{N} 1-\mathrm{C} 1$ & $1.404(4)$ & $\mathrm{Cl} 3-\mathrm{Co} 1-\mathrm{Cl} 2$ & $107.72(3)$ \\
\hline $\mathrm{N} 2-\mathrm{C} 2$ & $1.335(3)$ & $\mathrm{C} 4-\mathrm{N} 1-\mathrm{C} 1$ & $118.6(2)$ \\
\hline $\mathrm{N} 2-\mathrm{C} 1$ & $1.336(3)$ & $\mathrm{C} 2-\mathrm{N} 2-\mathrm{C} 1$ & $118.1(2)$ \\
\hline $\mathrm{N} 3-\mathrm{C} 2$ & $1.325(3)$ & $\mathrm{C} 10-\mathrm{N} 4-\mathrm{C} 7$ & $119.2(3)$ \\
\hline $\mathrm{N} 4-\mathrm{C} 10$ & $1.353(4)$ & $\mathrm{C} 7-\mathrm{N} 5-\mathrm{C} 8$ & $117.8(2)$ \\
\hline $\mathrm{N} 4-\mathrm{C} 7$ & $1.398(4)$ & $\mathrm{N} 2-\mathrm{C} 1-\mathrm{N} 1$ & $122.1(2)$ \\
\hline N5-C7 & $1.341(3)$ & $\mathrm{N} 5-\mathrm{C} 7-\mathrm{N} 4$ & $121.9(3)$ \\
\hline N5-C8 & $1.343(4)$ & N5-C7-C11 & $117.5(2)$ \\
\hline $\mathrm{N} 6-\mathrm{C} 8$ & $1.329(4)$ & $\mathrm{N} 4-\mathrm{C} 7-\mathrm{C} 11$ & $120.6(2)$ \\
\hline $\mathrm{C} 1-\mathrm{C} 5$ & $1.493(4)$ & $\mathrm{N} 5-\mathrm{C} 8-\mathrm{C} 9$ & $121.7(2)$ \\
\hline $\mathrm{C} 2-\mathrm{C} 3$ & $1.353(3)$ & $\mathrm{C} 8-\mathrm{C} 9-\mathrm{C} 10$ & $121.2(2)$ \\
\hline $\mathrm{C} 3-\mathrm{C} 4$ & $1.358(3)$ & $\mathrm{N} 4-\mathrm{C} 10-\mathrm{C} 9$ & $118.1(2)$ \\
\hline C7-C11 & $1.482(4)$ & $\mathrm{N} 4-\mathrm{C} 10-\mathrm{C} 12$ & $125.0(3)$ \\
\hline $\mathrm{C} 8-\mathrm{C} 9$ & $1.352(3)$ & $\mathrm{C} 9-\mathrm{C} 10-\mathrm{C} 12$ & $116.9(3)$ \\
\hline $\mathrm{C} 9-\mathrm{C} 10$ & $1.366(4)$ & & \\
\hline $\mathrm{C} 10-\mathrm{C} 12$ & $1.485(4)$ & & \\
\hline
\end{tabular}

The Co- $\mathrm{Cl}$ bond distances, in the range 2.2437 (8)-2.2843 (8) $\AA$, and the bond angles around the central atom, which vary between $108.54(4)^{\circ}$ and $111.02(5)^{\circ}$, show, on the 
one hand, that these values are comparable to those observed in other similar Co(II) complexes $[30,31]$ and, on the other hand, that the coordination geometry can be described as slightly distorted tetrahedral. This can be confirmed by the calculation of the Yang $\tau_{4}$ parameter [32] which indicates the degree of distortion of the geometry of a fourcoordinated metal complex. $\tau_{4}$ is calculated as $=[360-(\beta+\alpha)] / 141$, where $\beta$ and $\alpha$ are the two largest angles, and assumes the value of 0 and 1 for the perfect square planar and perfect tetrahedral geometries, respectively. For the present complex, the $\tau_{4}$ value is 0.97 $\left(\beta=112.39(4)^{\circ}\right.$ and $\left.\alpha=110.97(3)^{\circ}\right)$ indicating a quite small distortion from the regular tetrahedron.

The tetrahedra $\left[\mathrm{CoCl}_{4}\right]^{2-}$ are arranged parallel to the plane $(-110)$ in $\mathrm{x}=(2 \mathrm{n}+1) / 2$ between which the organic cations are grafted (Figure 5). In the crystal lattice, the pyrimidine derivatives are linked in dimers by N6-H ... N2 N3-H . . N5 hydrogen bonds. In turn, these dimers are connected to the $\left[\mathrm{CoCl}_{4}\right]^{2-}$ anions through $\mathrm{N}-\mathrm{H} \ldots \mathrm{Cl}$ intermolecular interactions involving the $\mathrm{NH}_{2}$ groups (Figure 5). The co-crystallized water molecules act as bridges between two inorganic anions forming $\mathrm{OH} \ldots \mathrm{Cl}$ hydrogen bonds with donor-acceptor distances of 3.288 (3) and 3.295 (3) Å (Table 5, Figure 6).

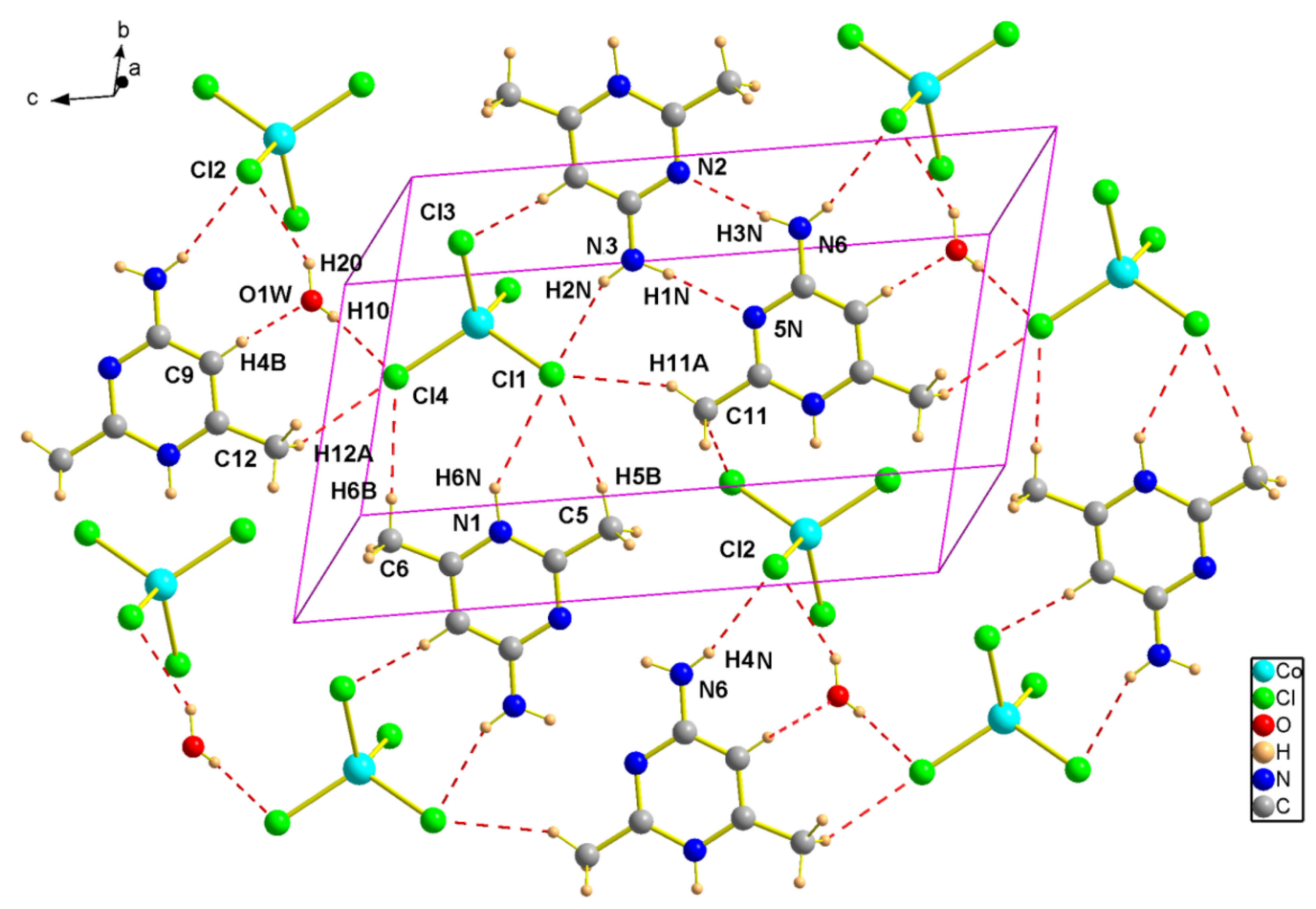

Figure 5. Representation of hydrogen bonds in the structure of (2).

Table 5. Hydrogen-bond geometry $\left(\AA,^{\circ}\right)$ in complex (2).

\begin{tabular}{ccccc}
\hline $\boldsymbol{D}-\mathbf{H} \cdots \boldsymbol{A}$ & $\boldsymbol{D}-\mathbf{H}$ & $\mathbf{H} \cdots \boldsymbol{A}$ & $\boldsymbol{D} \cdots \boldsymbol{A}$ & $\boldsymbol{D}-\mathbf{H} \cdots \boldsymbol{A}$ \\
\hline $\mathrm{C} 3-\mathrm{H} 3 \cdots \mathrm{Cl} 3^{\text {i }}$ & 0.93 & 2.18 & $3.107(2)$ & 174 \\
$\mathrm{C} 5-\mathrm{H} 5 B \cdots \mathrm{Cl1}{ }^{\text {ii }}$ & 0.96 & 2.83 & $3.761(3)$ & 164 \\
$\mathrm{C} 6-\mathrm{H} 6 B \cdots \mathrm{Cl} 4^{\text {ii }}$ & 0.96 & 2.86 & $3.776(3)$ & 160 \\
$\mathrm{C} 9-\mathrm{H} 4 B \cdots \mathrm{O} 1 W$ & 0.86 & 1.85 & $2.709(3)$ & 172 \\
$\mathrm{~N} 4 B-\mathrm{H} 4 B \cdots \mathrm{O} 1 W$ & 0.86 & 1.85 & $2.709(3)$ & 172 \\
$\mathrm{C} 11-\mathrm{H} 11 A \cdots \mathrm{Cl} 1^{\text {iii }}$ & 0.96 & 2.88 & $3.660(3)$ & 139 \\
$\mathrm{C} 11-\mathrm{H} 11 C \cdots \mathrm{Cl1} 1^{\text {ii }}$ & 0.96 & 2.94 & $3.855(3)$ & 160 \\
$\mathrm{C} 12-\mathrm{H} 12 A \cdots \mathrm{Cl} 4^{\text {iv }}$ & 0.96 & 2.92 & $3.695(3)$ & 138 \\
$\mathrm{C} 12-\mathrm{H} 12 B \cdots \mathrm{Cl3}{ }^{\mathrm{v}}$ & 0.96 & 2.95 & $3.742(4)$ & 140 \\
\hline
\end{tabular}


Table 5. Cont.

\begin{tabular}{ccccc}
\hline $\boldsymbol{D}-\mathbf{H} \cdots \boldsymbol{A}$ & $\boldsymbol{D}-\mathbf{H}$ & $\mathbf{H} \cdots \boldsymbol{A}$ & $\boldsymbol{D} \cdots \boldsymbol{A}$ & $\boldsymbol{D}-\mathbf{H} \cdots \boldsymbol{A}$ \\
\hline $\mathrm{N} 3-\mathrm{H} 1 N \cdots \mathrm{N} 5$ vi & $0.88(5)$ & $2.20(5)$ & $3.080(3)$ & $175(4)$ \\
$\mathrm{N} 3-\mathrm{H} 2 \mathrm{~N} \cdots \mathrm{Cl} 1^{\mathrm{i}}$ & $0.82(4)$ & $2.53(4)$ & $3.301(3)$ & $156(3)$ \\
$\mathrm{N} 6-\mathrm{H} 3 N \cdots \mathrm{N} 2{ }^{\text {vi }}$ & $0.85(4)$ & $2.21(4)$ & $3.054(3)$ & $168(4)$ \\
$\mathrm{N} 6-\mathrm{H} 4 N \cdots \mathrm{Cl}{ }^{\mathrm{i}}$ & $0.82(4)$ & $2.53(4)$ & $3.333(3)$ & $165(3)$ \\
$\mathrm{N} 1-\mathrm{H} 6 \mathrm{~N} \cdots \mathrm{Cl} 1^{\text {ii }}$ & $1.06(4)$ & $2.90(4)$ & $3.794(3)$ & $141(2)$ \\
$\mathrm{O} 1 W-\mathrm{H} 1 O \cdots \mathrm{Cl}{ }^{\text {iv }}$ & $0.88(2)$ & $2.43(2)$ & $3.288(3)$ & $167(5)$ \\
$\mathrm{O} 1 W-\mathrm{H} 2 \mathrm{O} \cdots \mathrm{Cl} 2^{\mathrm{i}}$ & $0.86(2)$ & $2.57(3)$ & $3.295(3)$ & $142(4)$ \\
\hline
\end{tabular}

Symmetry codes: (i) $\mathrm{x}+1, \mathrm{y}, \mathrm{z}$; (ii) $\mathrm{x}, \mathrm{y}-1, \mathrm{z}$; (iii) $-\mathrm{x},-\mathrm{y},-\mathrm{z}+1$; (iv) $-\mathrm{x},-\mathrm{y},-\mathrm{z}$; (v) $\mathrm{x}+1, \mathrm{y}-1, \mathrm{z}$; and (vi) $-\mathrm{x}+$ $1,-\mathrm{y},-\mathrm{z}+1$.

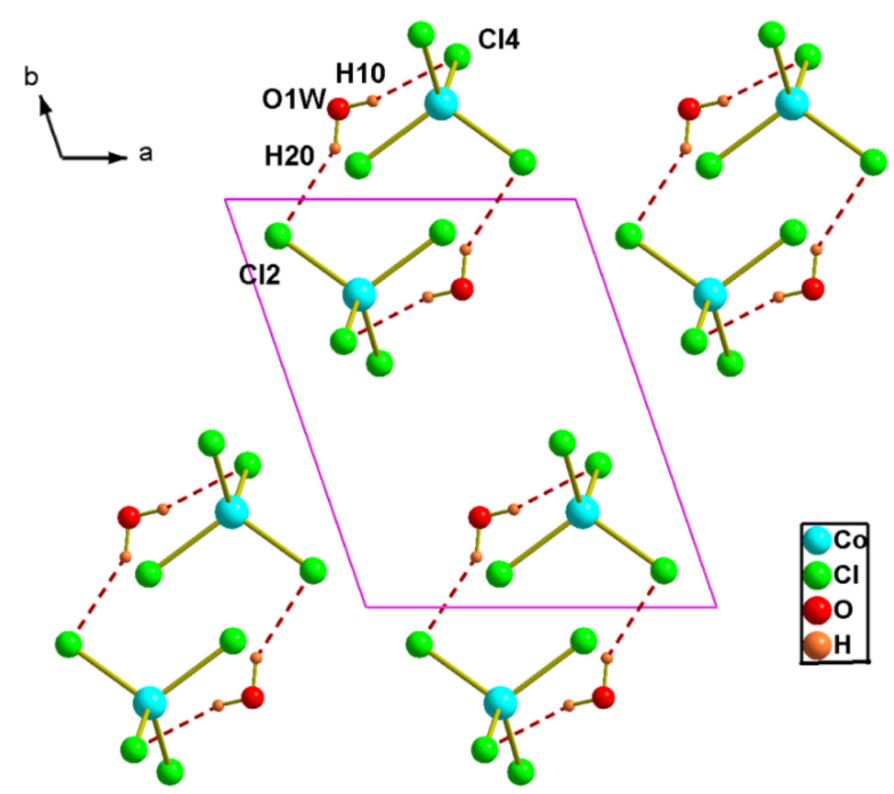

Figure 6. Projection of an inorganic layer in (2) along the c-axis direction. Dotted lines indicate hydrogen bonds.

\subsection{Hirshfeld Surface and Enrichment Ratio}

The Hirshfeld surface is representative of the region in space where molecules come into contact with each other, allowing the analysis of the chemical nature of intermolecular interactions in the crystal. The contact enrichment ratio is obtained by comparing the actual contacts $C_{X Y}$ in the crystal with those computed as if all types of contacts had the same probability to form. An enrichment ratio larger than unity for a given pair of chemical species X ... Y indicates that these contacts are over-represented in the crystal [33]. The analysis of contact types and their enrichment were computed with the CrystalExplorer software [34]. The Hirshfeld surfaces of both compounds (1) \& (2) were calculated with the two-dimensional fingerprint plots, which represent the percentage of the actual contacts in both compounds. The Hirshfeld surfaces around each moiety in the asymmetric unit of both compounds are shown in the $d_{\text {norm }}$ representation with a color scheme: red blue and white, while the intensive red spots represent the shortest intermolecular contacts between nearest neighbor molecules (Figure 7). 


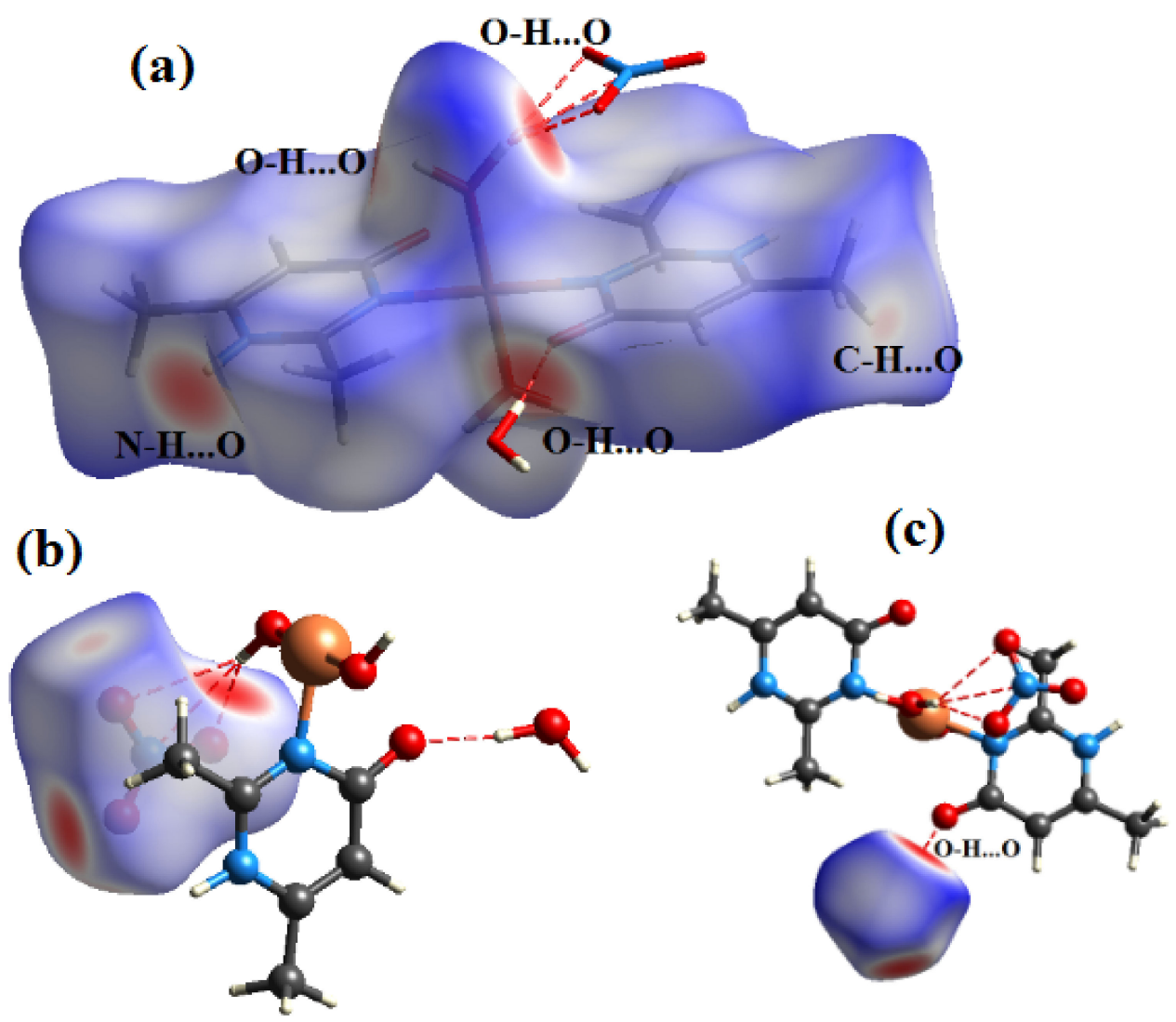

Figure 7. View of the $d_{\text {norm }}$ mapped on the Hirshfeld surface of compound (1) (the red spots represents intermolecular contacts between atoms). (a) around the complex ion, (b) around the nitrate anion and (c) around the water molecule.

\subsubsection{Study of $\left[\mathrm{Cu}(\text { dimpyr })_{2}\left(\mathrm{H}_{2} \mathrm{O}\right)_{2}\right]\left(\mathrm{NO}_{3}\right)_{2} \cdot 2 \mathrm{H}_{2} \mathrm{O}(\underline{\mathbf{1}})$}

In the compound (1), the intermolecular interactions around $\mathrm{Cu}(\operatorname{dimpyr})_{2}\left(\mathrm{H}_{2} \mathrm{O}\right)_{2}$, the $\mathrm{NO}_{3}$ group and the $\mathrm{H}_{2} \mathrm{O}$ molecule in the asymmetric unit have been quantified separately (see Figure 8 ). The $\mathrm{Cu}(\text { dimpyr })_{2}\left(\mathrm{H}_{2} \mathrm{O}\right)_{2}$ moiety has $63.2 \%$ of $\mathrm{H}$ and $27.45 \%$ of $\mathrm{O}$ atom types on the Hirshfeld molecular surface that highlights the preponderance of strong $\mathrm{H}$... O hydrogen bonds in the ligand 2,6-dimethylpyrimidine-4- $(1 H)$-one $\left(48,5 \%, \mathrm{E}_{\mathrm{O}} \ldots \mathrm{H}=1.39\right)$. This result corresponds to $\mathrm{O}-\mathrm{H} \ldots \mathrm{O}, \mathrm{N}-\mathrm{H} \ldots \mathrm{O}$ and $\mathrm{C}-\mathrm{H} \ldots \mathrm{O}$ hydrogen bonds between the ligand, the water molecules and the nitrate groups. (Figures 7a and 8a). The H ... H contacts are the next most abundant interactions (34.7\%), but these hydrophobic contacts are under-represented $\left(\mathrm{E}_{\mathrm{HH}}=0.86\right)($ Table $6 \mathrm{a}$, Figure $7 \mathrm{~b})$.

The ligand contains $3.9 \%$ carbon and $63.2 \%$ hydrogen on the molecular surface and the C ... H contacts show an enrichment ratio around 0.91 and become the third most frequent interactions, which correspond to $\mathrm{C}-\mathrm{H} \ldots \mathrm{C}$ and $\mathrm{C}-\mathrm{H} \ldots \pi$ hydrogen bonds (Figure 8c). The $\mathrm{Cu} \ldots \mathrm{N}$ contacts are extremely enriched with an enrichment ratio around 12.93, highlighting the coordination of the copper atom with the two nitrogen atoms $\mathrm{N} 1$ and $\mathrm{N} 1^{\mathrm{i}}$ of the ligand. It is also noteworthy that the $\mathrm{Cu}$... O contacts present an enrichment ratio equal to 0.91 , explaining the coordination of $\mathrm{Cu}^{++}$to the two oxygen atoms of carbonyl groups of ligands.

All other self-contacts which involve chemical types $(\mathrm{C}, \mathrm{N}, \mathrm{Cu})$ are completely avoided. Also, the $\mathrm{O}^{\delta-} \ldots \mathrm{O}^{\delta-}, \mathrm{C} \ldots \mathrm{O}$ and $\mathrm{H}^{\delta+} \ldots \mathrm{Cu}^{++}$contacts are impoverished with enrichment ratios equals to $0.09,0.11$ and 0.43 , respectively. The $C \ldots N$ contacts with the smallest surface are very enriched $\mathrm{E}_{\mathrm{C}} \ldots \mathrm{N}=3.16$ (Table 6); they correspond to the strong interactions between the ligand 2,6-dimethylpyrimidine-4-(1H)-one and the nitrate groups. 

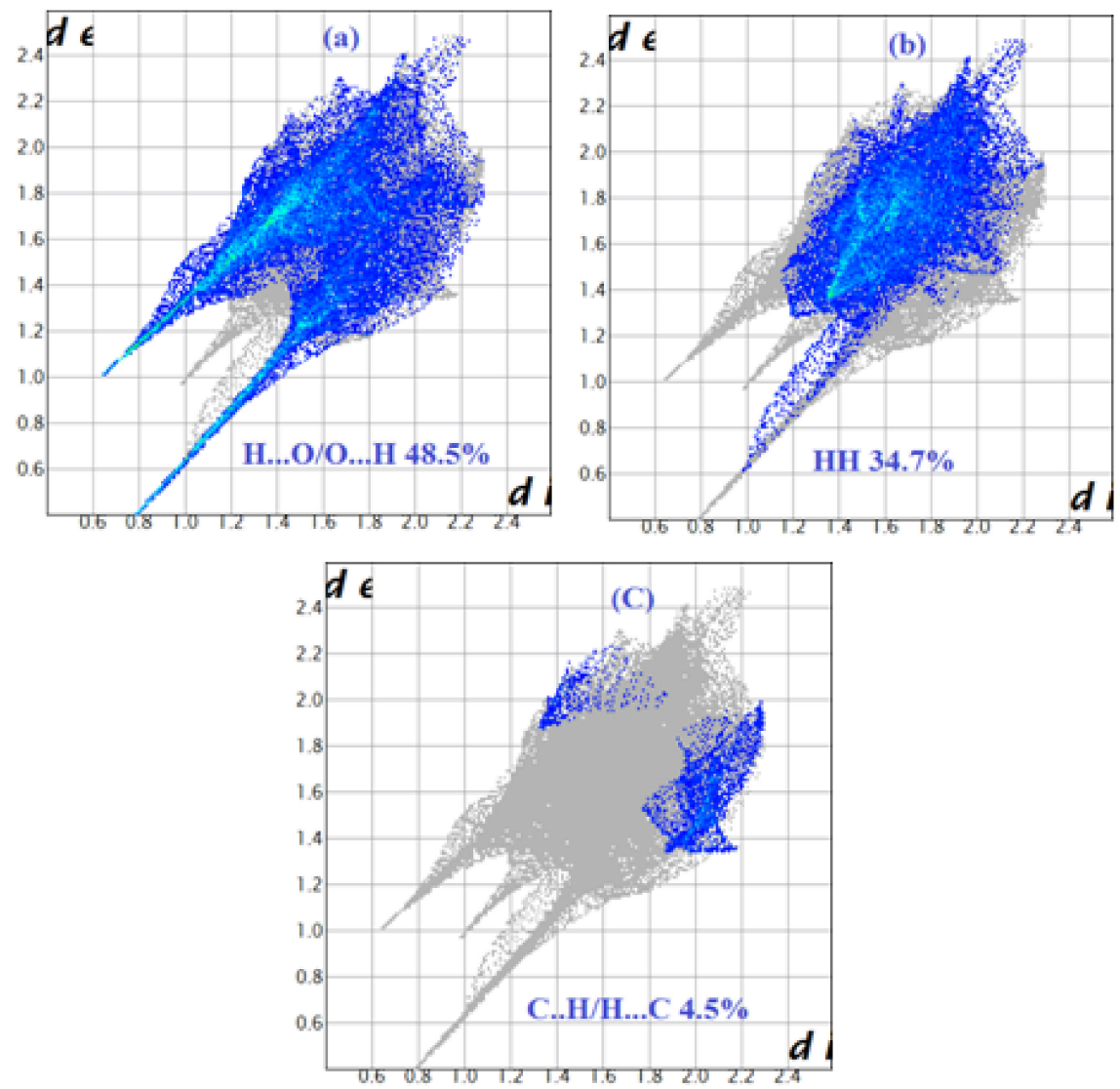

Figure 8. Decomposed fingerprint plots of the major contacts around $\mathrm{Cu}(\operatorname{dimpyr})_{2}\left(\mathrm{H}_{2} \mathrm{O}\right)_{2} \cdot(\mathbf{a}-\mathbf{c})$ represent $\mathrm{H} \ldots \mathrm{O}, \mathrm{H} \ldots \mathrm{H}$ and $\mathrm{C} \ldots \mathrm{H}$ contacts, respectively.

Table 6. Chemical proportions on the Hirshfeld surface and major interactions of the compound (1): (a) around the $\mathrm{Cu}(\text { dimpyr })_{2}\left(\mathrm{H}_{2} \mathrm{O}\right)_{2},(\mathbf{b})$ around the nitrate group, and (c) around the water molecule.

\begin{tabular}{|c|c|c|c|c|c|c|}
\hline$\%$ surface & $\begin{array}{c}\mathrm{C} \\
3.9\end{array}$ & $\begin{array}{c}\mathbf{H} \\
63.2\end{array}$ & $\begin{array}{l}\mathrm{Cu} \\
1.8\end{array}$ & $\begin{array}{c}\mathrm{N} \\
3.65\end{array}$ & $\begin{array}{c}\mathbf{O} \\
27.45\end{array}$ & \\
\hline $\begin{array}{c}\% \text { contacts } \\
\text { (Major contacts) }\end{array}$ & $\underset{4.5}{\text { H ... C }}$ & $\begin{array}{c}\mathbf{H} \ldots \mathbf{H} \\
34.7\end{array}$ & $\begin{array}{c}\text { H... O } \\
48.5\end{array}$ & $\begin{array}{c}\mathrm{Cu} \ldots \mathrm{O} \\
0.9\end{array}$ & $\begin{array}{c}\mathrm{Cu} \ldots \mathrm{N} \\
1.7\end{array}$ & $\begin{array}{c}\text { C ... N } \\
0.9\end{array}$ \\
\hline Enrichment $(x, y)$ & 0.91 & 0.86 & 1.39 & 0.91 & 12.93 & 3.16 \\
\hline \multicolumn{7}{|l|}{ (b) } \\
\hline \multirow{2}{*}{$\%$ surface } & $\mathbf{O}$ & $\mathbf{H}$ & $\mathbf{N}$ & $\mathrm{Cu}$ & $\mathrm{C}$ & \\
\hline & 47.9 & 44.8 & 4.15 & 0 & 3.15 & \\
\hline $\begin{array}{c}\% \text { contacts } \\
\text { (Major contacts) }\end{array}$ & $\underset{86.9}{\mathbf{H} \ldots \mathbf{O}}$ & $\begin{array}{c}\text { C ... O } \\
3.8\end{array}$ & $\begin{array}{c}\mathbf{O} \ldots \mathbf{N} \\
3.1\end{array}$ & $\begin{array}{c}\mathrm{N} \ldots \mathrm{H} \\
2.7\end{array}$ & $\begin{array}{c}\text { C .. N N } \\
2.5\end{array}$ & \\
\hline Enrichment $(x, y)$ & 2.024 & 0.12 & 0.77 & 0.72 & 9.56 & \\
\hline \multicolumn{7}{|l|}{ (c) } \\
\hline \multirow{2}{*}{$\%$ surface } & $\mathrm{O}$ & $\mathbf{H}$ & $\mathbf{N}$ & $\mathrm{Cu}$ & $\mathrm{C}$ & \\
\hline & 32.55 & 62.55 & 1.55 & 0 & 3.35 & \\
\hline $\begin{array}{c}\% \text { contacts } \\
\text { (Major contacts) }\end{array}$ & $\underset{64.1}{\mathrm{H} \ldots \mathrm{O}}$ & $\begin{array}{c}\text { С...H } \\
5.7\end{array}$ & $\begin{array}{c}\mathbf{H} \ldots . \mathbf{N} \\
3.1\end{array}$ & $\begin{array}{c}C \ldots 0 \\
1\end{array}$ & $\begin{array}{c}\mathrm{H} \ldots \mathrm{H} \\
26.1\end{array}$ & \\
\hline Enrichment $(x, y)$ & 1.57 & 1.36 & 1.59 & 0.04 & 0.66 & \\
\hline
\end{tabular}


For the nitrate group, the $\mathrm{O} \ldots \mathrm{H}$ contacts are the first most frequent interactions, which comprise $86.9 \%$ of the total Hirshfeld surface area and are very enriched with $\mathrm{E}_{\mathrm{OH}}=2.02$ (Figure S1a in the Supplementary Materials, Table 6). They correspond to all $\mathrm{C}-\mathrm{H} \ldots \mathrm{O}\left(\mathrm{C} 6-\mathrm{H} \ldots \mathrm{O} 4^{\mathrm{iii}}\right), \mathrm{N}-\mathrm{H} \ldots \mathrm{O}\left(\mathrm{N} 2-\mathrm{H} \ldots \mathrm{O} 2^{\mathrm{i}}\right)$ and $\mathrm{OW}-\mathrm{H} \ldots \mathrm{O}(\mathrm{O} 1 \mathrm{~W}-\mathrm{H} \ldots \mathrm{O} 3)$ interactions existing in the crystal structure (Table 3). Furthermore, the $\mathrm{C} \ldots \mathrm{N}$ contacts are extremely enriched with $E_{C} \ldots N=9.56$ around the nitrate group of the coordinated compound (1) and correspond to the presence of strong interactions between the ligand molecule and these nitrate groups. The resulting $\mathrm{H} \ldots \mathrm{N}$ and $\mathrm{O} \ldots \mathrm{N}$ interactions represent $2.7 \%$ and $3.1 \%$, respectively, of the contact surface. They are moderately enriched with enrichment ratios equal to 0.72 and 0.77 ; these favorable interactions also are an important contribution to the crystal stability compound.

For the water of crystallization, the $\mathrm{H} \ldots \mathrm{O}$ contacts are enriched with an enrichment ratio larger than the unity and these contacts become the major contact around this molecule $\left(64.1 \%\right.$ and $\left.\mathrm{E}_{\mathrm{O}} \ldots \mathrm{H}=1.57\right)$ and correspond to interactions with the carbonyl groups (O3W$\mathrm{H} \ldots \mathrm{O} 1)$ and with coordinated water molecules $\left(\mathrm{O} 2 \mathrm{~W}-\mathrm{H} \ldots \mathrm{O} 3 \mathrm{~W}^{\mathrm{iv}}\right)$ (Table 3, Figure S2a). This suggests that these strong attractions are the driving force in the crystal packing formation. The $\mathrm{C} \ldots \mathrm{H}$ and $\mathrm{N} \ldots \mathrm{H}$ contacts present enrichment ratios larger than unity (1.36 and 1.59).

\subsubsection{Study of (Hamdimpy) $)_{2}\left[\mathrm{CoCl}_{4}\right] \cdot \mathrm{H}_{2} \mathrm{O}(\underline{2})$}

For the compound (Hamdimpy) ${ }_{2}\left[\mathrm{CoCl}_{4}\right] \cdot \mathrm{H}_{2} \mathrm{O}(\underline{2})$, the Hirshfeld surface was computed around the two cations 2-amino-4,6-dimetylpyrimidine, the tetrachlorocobaltate(II) $\left[\mathrm{CoCl}_{4}\right]^{2-}$, and the water molecule separately. The $\mathrm{d}_{\text {norm }}$ map of all entities is shown in Figure 9. It shows intensive red-hot spots that correspond to interactions between the water molecule and the $\left[\mathrm{CoCl}_{4}\right]^{2-}$ anion. The fingerprint plots of the intermolecular contacts for the organic molecule are shown in Figure S3.

(b)

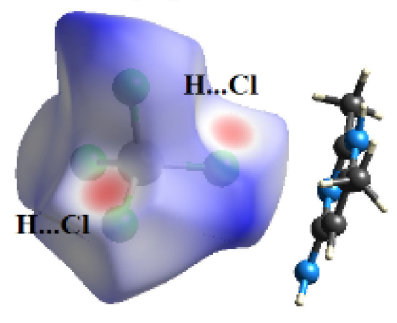

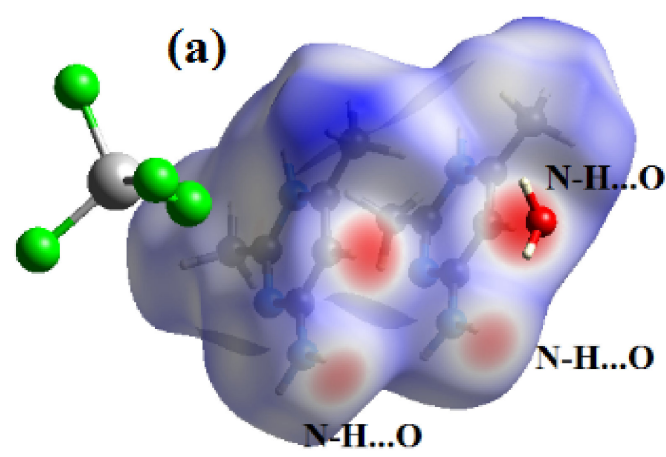

(c)
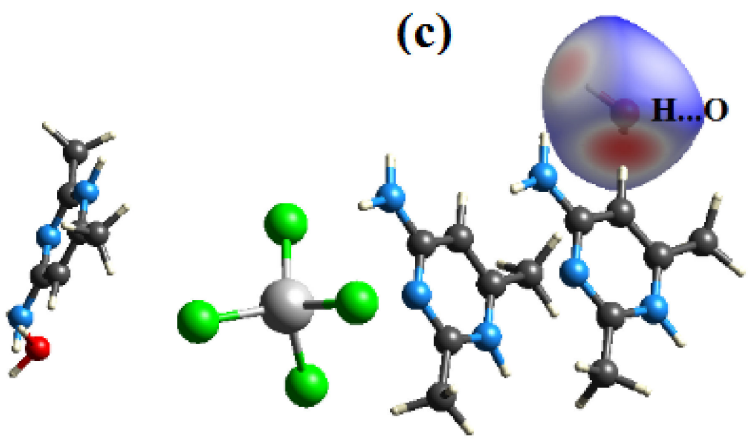

Figure 9. View of the $d_{\text {norm }}$ mapped on the Hirshfeld surface of compound (2) (the red spots represents intermolecular contacts between atoms). (a) around the organic cation, (b) around the complex anion and (c) around the water molecule.

The $\mathrm{H} \ldots \mathrm{H}$ and $\mathrm{H} \ldots \mathrm{Cl}$ intermolecular interactions are the most abundant contacts of both organic cations in the crystal packing $(47.4 \%$ and $27.1 \%$, respectively). There are seven $\mathrm{C}-\mathrm{H} \ldots \mathrm{Cl}$, three $\mathrm{N}-\mathrm{H} \ldots \mathrm{Cl}$ and two $\mathrm{OW}-\mathrm{H} \ldots \mathrm{Cl}$ hydrogen bonds in the 
crystal structure (see Tables 5 and 7 ). The $\mathrm{H}$... H hydrophobic contacts are the first most frequent interactions, which is related to the abundance of hydrogen $(71.75 \%)$ on the cation surface, but these contacts are under-represented with enrichment ratio lower than unity $\left(\mathrm{E}_{\mathrm{HH}}=0.92\right)[35]$. The $\mathrm{H} \ldots \mathrm{Cl}^{-}$contacts are electrostatically favorable due to the partial positive charge, $\delta^{+}$of $\mathrm{H}$ atoms and the negative charge $\delta^{-}$of $\mathrm{Cl}$ and are enriched with an enrichment ratio equal to 1.21 .

Table 7. Chemical proportions on the Hirshfeld surface and major interactions of the compound (2): (a) around the both organic cations, (b) around the $\left[\mathrm{CoCl}_{4}\right]^{2-}$ and (c) around the water molecule.

\begin{tabular}{|c|c|c|c|c|c|c|}
\hline \multicolumn{7}{|l|}{ (a) } \\
\hline \multirow{2}{*}{$\%$ surface } & C & $\mathbf{H}$ & $\mathrm{Cl}$ & Co & $\mathbf{N}$ & $\mathbf{O}$ \\
\hline & 3.35 & 71.75 & 15.5 & 0.35 & 7.05 & 2 \\
\hline$\%$ contacts & H...C & H...H & $\mathrm{H} \ldots \mathrm{Cl}$ & $\mathbf{H} \ldots \mathbf{N}$ & H... O & C... Cl \\
\hline (Major contacts) & 3.7 & 47.4 & 27.1 & 13.2 & 4 & 3.0 \\
\hline Enrichment $(x, y)$ & 0.76 & 0.92 & 1.21 & 1.30 & 1.39 & 2.88 \\
\hline \multicolumn{7}{|l|}{ (b) } \\
\hline \multirow{2}{*}{$\%$ surface } & O & $\mathbf{H}$ & $\mathrm{Cl}$ & Co & $\mathrm{C}$ & \\
\hline & 0 & 45.85 & 49.75 & 0.85 & 2.65 & \\
\hline$\%$ contacts & H ... Co & $\mathrm{C} \ldots \mathrm{Cl}$ & $\mathrm{H} \ldots \mathrm{Cl}$ & $\mathbf{N} \ldots \mathrm{Cl}$ & $\mathrm{Cl} \ldots \mathrm{Cl}$ & \\
\hline (Major contacts) & 1.7 & 5.3 & 90 & 1.8 & 1.2 & \\
\hline Enrichment $(\mathrm{x}, \mathrm{y})$ & 2.18 & 2.01 & 1.97 & 2.01 & 0.04 & \\
\hline \multicolumn{7}{|l|}{ (c) } \\
\hline \multirow{2}{*}{$\%$ surface } & $\mathrm{O}$ & $\mathbf{H}$ & $\mathrm{Cl}$ & Co & & \\
\hline & 1.75 & 66.35 & 18.3 & 0.25 & & \\
\hline$\%$ contacts & $\mathrm{H} \ldots \mathrm{O}$ & $\mathbf{H} \ldots \mathbf{H}$ & $\mathrm{H} \ldots \mathrm{Cl}$ & H ... Co & & \\
\hline (Major contacts) & 30.4 & 32.6 & 36.6 & 0.5 & & \\
\hline Enrichment $(x, y)$ & 1.50 & 0.74 & 1.50 & 1.50 & & \\
\hline
\end{tabular}

The $\mathrm{H}$... N contacts account for $13.2 \%$ of the organic cation interactions as there are two strong hydrogen bonds (N-H ... N) present in the crystal structure (Table 5). The $\mathrm{C} \ldots \mathrm{Cl}$ interactions are very enriched $\left(\mathrm{E}_{\mathrm{C}} \ldots \mathrm{Cl}=2.88\right)$, referring to interactions between the anions and the organic cations.

For $\left[\mathrm{CoCl}_{4}\right]^{2-}$, the four chlorine make contacts with hydrogen atoms $(90 \%$ of their Hirshfeld surface), with carbon (5.3\%) followed by chlorine $(1.2 \%)$. Therefore, the contacts of $\mathrm{Cl}^{-}$ions in the crystal structure are essentially ionic bridges and hydrogen bonds, while the few chloride-chloride contacts are presumably a result of interaction between the tetrachlorocobalte (II) anions. Additionally, the nature of interactions of the chlorine and cobalt ions can result in $\mathrm{Cl} \ldots \mathrm{C}$ and $\mathrm{Co} \ldots \mathrm{H}$, which are very enriched with enrichment ratio equal to 2.88 and 2.18 , respectively (Figure 10, Table 7).

The water molecule is surrounded by organic cations, water molecules and several chloride anions; therefore most of the contacts of the water molecule result in $\mathrm{H} \ldots \mathrm{Cl}$, $\mathrm{H} \ldots \mathrm{H}, \mathrm{H} \ldots \mathrm{O}$ and $\mathrm{H} \ldots$. . Co contacts (Figure S4 and Table 7). These contacts are enriched with enrichment ratios equal to $1.50,0.74,1.50$ and 1.50 , respectively. 

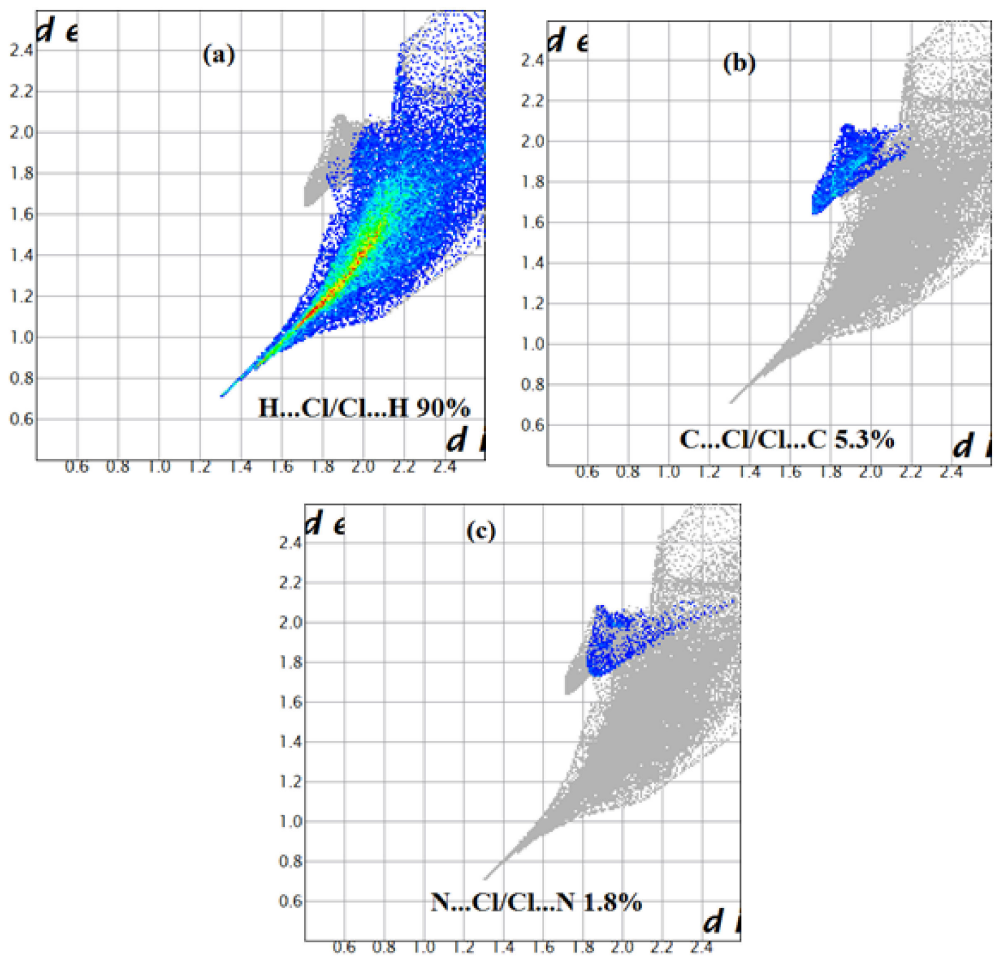

Figure 10. Decomposed fingerprint plots of the major contacts around the $\left[\mathrm{CoCl}_{4}\right]^{2-}$ of compound (2). (a-c) represent $\mathrm{H} \ldots \mathrm{Cl}, \mathrm{C} \ldots \mathrm{Cl}$ and $\mathrm{N} \ldots \mathrm{Cl}$ contacts, respectively.

\subsection{Quantum Mechanical Studies}

\subsubsection{Quantum Mechanical Study of Compound (1)}

Quantum chemical calculations were performed on the copper complex from the crystal data with the DFT method at the B3LYP/6-31+G* level, using the Gaussian 09 program [36]. The HOMO and LUMO molecular orbitals were determined (Figure 11). The HOMO orbital is located on one of the two organic molecules, while the LUMO is located on the two organic molecules. The energy gap between HOMO and LUMO is 5.59 $\mathrm{eV}$ for the complex. This value implies high kinetic stability and low chemical reactivity for compound (1) $[37,38]$.

The density of state (DOS) spectrum was plotted with the GaussSum software using information from the Gaussian output file and is shown in Figure S5. Such a spectrum shows the number of available molecular orbitals including compositions and their contributions to the chemical bonding at different levels of energies. The red and green lines of the plot indicate the virtual and occupied orbitals, respectively, and also provide an understanding of the molecular orbital character in a particular area. The DOS plot and its energy levels also corroborate the Frontier Molecular orbital's analysis.

\subsubsection{Quantum Mechanical Study of Compound (2)}

Quantum chemical calculations were performed from the crystal data with the DFT method at the B3LYP /6-31+G* level, using the Gaussian 09 program [27]. The calculations were made on a system containing the two organic molecules and the water molecule in interaction with them. The HOMO and LUMO molecular orbitals were determined (Figure 12). The HOMO orbital is located on one of the two aromatic rings, while the LUMO orbital is located on the two aromatic rings. The large HOMO-LUMO energy gap of $5.47 \mathrm{eV}$ also corresponds to high stability. The energy distribution of the different orbitals is shown in Figure S6. 


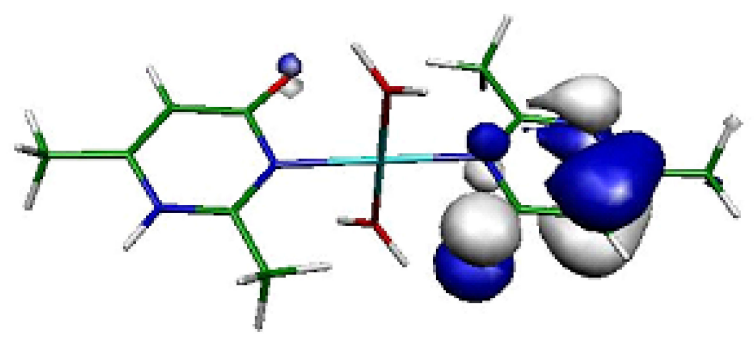

$E(H O H O)=-13.310 \mathrm{eV}$

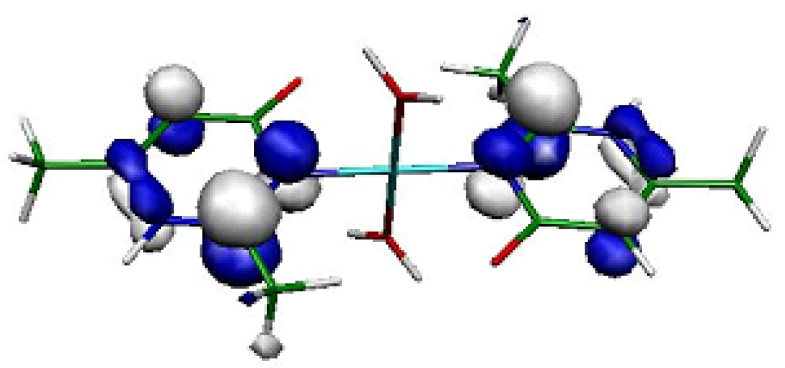

$\mathrm{E}(\mathrm{LUhO})=-7.721 \mathrm{eV}$

Figure 11. Frontier orbitals in (1).
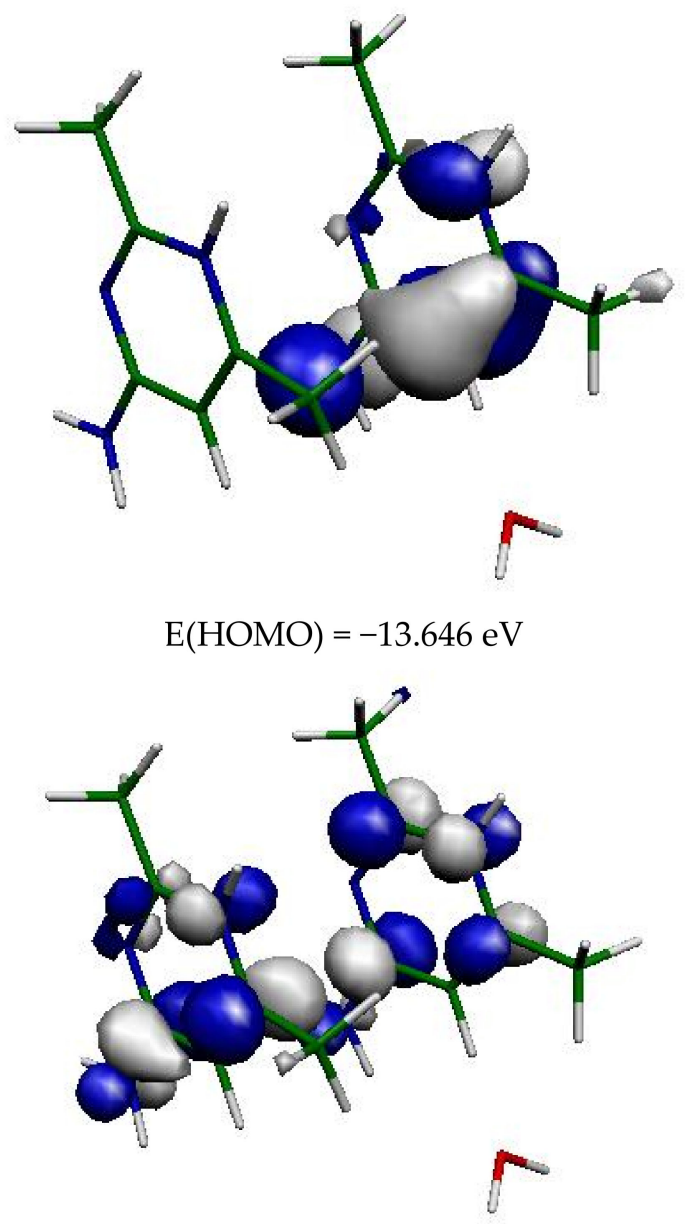

$\mathrm{E}(\mathrm{LUMO})=-8.179 \mathrm{eV}$

Figure 12. Frontier orbitals of the two organic cations in (2). 


\subsection{Molecular Electrostatic Potential Analysis}

3.4.1. Molecular Electrostatic Potential Analysis of Compound ( $\underline{\mathbf{1}})$

The Molecular Electrostatic Potential (MEP) surface of (1) is depicted in Figure 13. The MEP is used to determine the nuclear and electronic charge distribution of a given molecule. The maps were obtained at the B3LYP $/ 6-31+G^{*}$ level of theory. As it can be seen, the electrostatic potential maps are color-coded and are subdivided into many regions. Moreover, blue and red colors indicate the positive and negative potentials, respectively. The most positive areas are on the protons of water molecules in particular; the negative areas are on the oxygen linked to the aromatic rings, in agreement with the Mulliken charges (see below, Table 8).

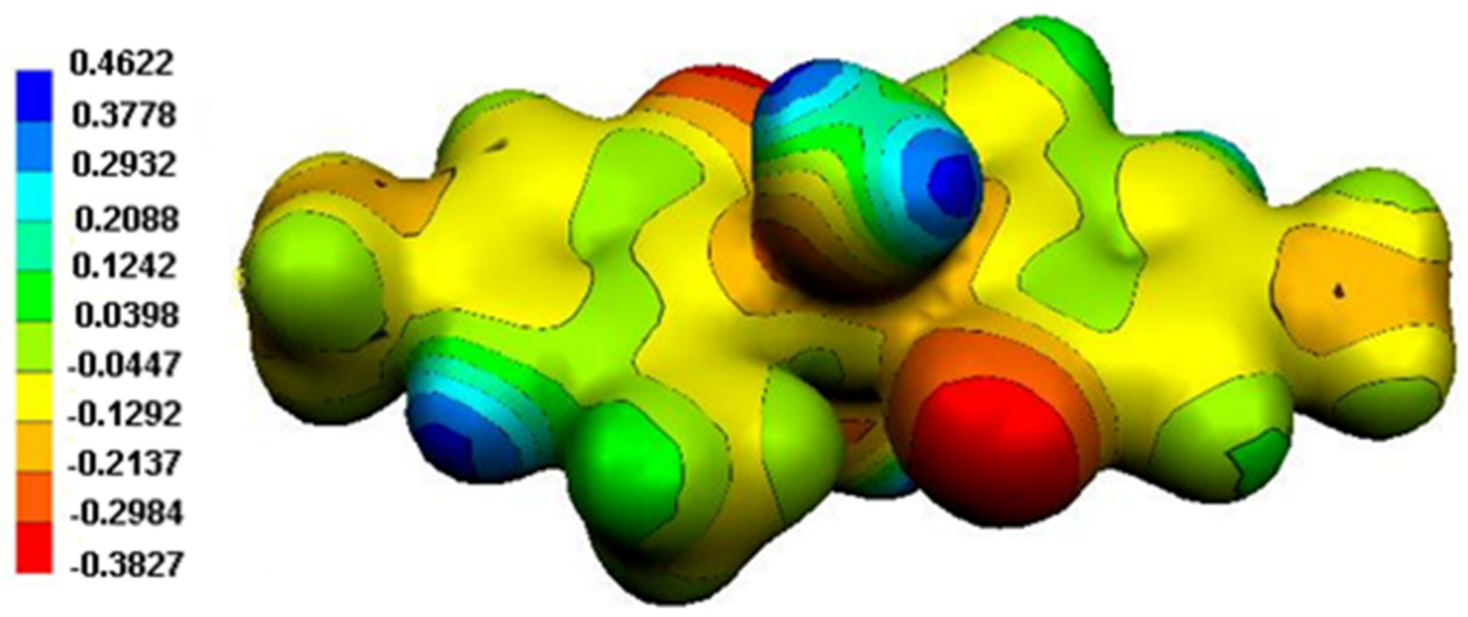

Figure 13. MEP surface of ( $\underline{\mathbf{1}})$.

Table 8. Mulliken charge distribution of all atoms in ( $\underline{\mathbf{1}})$.

\begin{tabular}{ccc}
\hline Atom & Ligand 1 & Ligand 2 \\
\hline $\mathrm{Cu}$ & 0.407335 & \\
\hline $\mathrm{O}\left(\mathrm{H}_{2} \mathrm{O}\right)$ & -0.955452 & -0.942977 \\
\hline $\mathrm{H}\left(\mathrm{H}_{2} \mathrm{O}\right)$ & 0.571069 & 0.571055 \\
& 0.571090 & 0.571056 \\
\hline $\mathrm{O} 1$ & -0.469507 & -0.469515 \\
\hline $\mathrm{N} 3$ & -0.284973 & -0.284893 \\
\hline $\mathrm{C} 4$ & 0.398537 & 0.398420 \\
\hline $\mathrm{N} 5$ & -0.481902 & -0.481840 \\
\hline $\mathrm{H}(\mathrm{N} 5)$ & 0.478716 & 0.478724 \\
\hline $\mathrm{C} 6$ & 0.348863 & 0.348852 \\
\hline $\mathrm{C} 7$ & -0.380229 & -0.380187 \\
\hline $\mathrm{H}(\mathrm{C} 7)$ & 0.258462 & 0.258462 \\
\hline $\mathrm{C} 8$ & 0.596716 & 0.596699 \\
\hline $\mathrm{C} 9$ & -0.728109 & -0.728081 \\
\hline $\mathrm{H}(\mathrm{C} 9)$ & 0.283773 & 0.283764 \\
& 0.273563 & 0.273566 \\
\hline & 0.288628 & 0.288631 \\
\hline & & \\
\hline
\end{tabular}


Table 8. Cont.

\begin{tabular}{ccc}
\hline Atom & Ligand 1 & Ligand 2 \\
\hline $\mathrm{C} 10$ & -0.772044 & -0.772060 \\
\hline & 0.263820 & 0.263822 \\
$\mathrm{H}(\mathrm{C} 10)$ & 0.266023 & 0.266025 \\
& 0.263049 & 0.263051 \\
\hline
\end{tabular}

3.4.2. Molecular Electrostatic Potential Analysis of Compound (2)

The Molecular Electrostatic Potential (MEP) surface of the system of the two organic cations and the water molecule is depicted in Figure 14. The positive areas, blue-colored, correspond to protons, especially those of the water molecules, while the negative areas, redcolored, are located on methyl groups, in agreement with the Mulliken charges (Table 9).
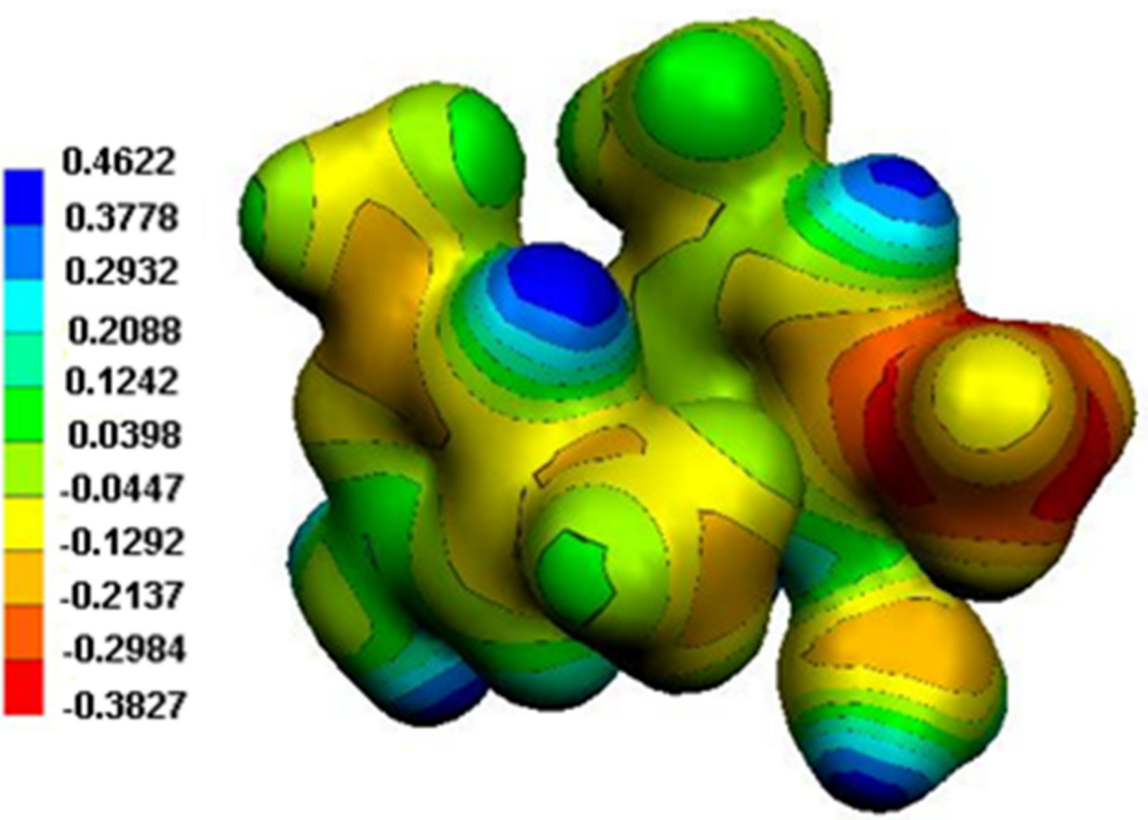

Figure 14. MEP surface of the two organic cations in (2).

Table 9. Mulliken charge distribution of organic atoms and water in (2).

\begin{tabular}{ccc}
\hline Atom & Ligand 1 & Ligand 2 \\
\hline $\mathrm{N} 1$ & -0.083517 & -0.059330 \\
\hline $\mathrm{C} 2$ & 0.056605 & 0.300591 \\
\hline $\mathrm{N} 3$ & -0.403974 & -0.412695 \\
\hline $\mathrm{H}(\mathrm{N} 3)$ & 0.478801 & 0.476501 \\
\hline $\mathrm{C} 4$ & 0.225706 & -0.010665 \\
\hline $\mathrm{C} 5$ & -0.211047 & 0.274921 \\
\hline $\mathrm{H}(\mathrm{C} 5)$ & 0.217385 & 0.322349 \\
\hline $\mathrm{C} 6$ & 0.572397 & 0.031016 \\
\hline $\mathrm{C} 7$ & -0.712512 & -0.755072 \\
\hline $\mathrm{H}(\mathrm{C} 7)$ & 0.286429 & 0.272446 \\
& 0.227082 & 0.291717 \\
\hline & 0.298176 & 0.246250 \\
\hline
\end{tabular}


Table 9. Cont.

\begin{tabular}{ccc}
\hline Atom & Ligand 1 & Ligand 2 \\
\hline $\mathrm{C} 8$ & -0.834715 & -1.000509 \\
\hline & 0.296738 & 0.252751 \\
$\mathrm{H}(\mathrm{C} 8)$ & 0.239734 & 0.285858 \\
& 0.245535 & 0.281142 \\
\hline $\mathrm{N} 9$ & -0.793196 & -0.734756 \\
\hline $\mathrm{H}(\mathrm{N9})$ & 0.458123 & 0.454368 \\
& 0.433036 & 0.442267 \\
\hline $\mathrm{O}\left(\mathrm{H}_{2} \mathrm{O}\right)$ & -0.979320 & \\
\hline $\mathrm{H}\left(\mathrm{H}_{2} \mathrm{O}\right)$ & 0.511459 & \\
\hline
\end{tabular}

\subsection{Mulliken Population Analysis}

\subsubsection{Mulliken Population Analysis of Compound (1)}

The Mulliken charge distribution of all atoms in (1) is given in Table 8. All atoms in the asymmetric unit are listed. The atoms are numbered as follows (Scheme 2):<smiles></smiles>

Scheme 2. The atomic numbering used for Mulliken charge calculation of ( $\underline{\mathbf{1}})$.

The atomic charge distribution shows that the copper ion has a positive charge of 0.407 , while the two nitrogen atoms have negative charges of -0.285 and -0.481 . For the two methyl groups, the carbon atoms C9 and C10 have negative charges of -0.728 and -0.771 , respectively. The oxygen atom of the two ligands has a negative charge of -0.469 . The $\mathrm{C} 4, \mathrm{C} 6$ and $\mathrm{C} 8$ carbon atoms of the pyrimidine ring have positive charges of $0.398,0.348$ and 0.596 , respectively, while the $C 7$ atom has a negative charge of -0.380 . All hydrogen atoms carry positive charge in the range $0.258-0.571$.

\subsubsection{Mulliken Population Analysis of (2)}

The Mulliken charge distribution of all atoms in the system of the two organic molecules in (2) is given in Table 9. The atoms are numbered as follows (Scheme 3):<smiles>Cc1cc(N)nc(C)[nH+]1</smiles>

Scheme 3. The atomic numbering used for Mulliken charge calculation of (2).

The atomic charge distribution shows that the carbon atoms $\mathrm{C} 7$ and $\mathrm{C} 8$ of the two methyl groups have negative charges of $(-0.712$ and -0.755$)$ and $(-0.834$ and -1.000$)$, respectively, in agreement with the MEP results. The C2 and C6 carbon atoms of the 
pyrimidine ring have positive charges for the two ligands, while the $\mathrm{C} 4$ and $\mathrm{C} 5$ carbons have different charges for each of the two ligands. For the two ligands, all nitrogen atoms have negative charges. The oxygen atom of the water molecule has a negative charge. All hydrogen atoms carry positive charge in the range $0.217-0.511$.

\subsection{IR Spectroscopy}

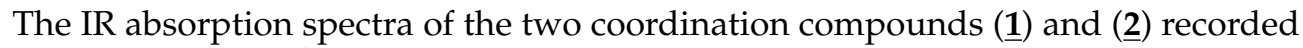
between $500-4000 \mathrm{~cm}^{-1}$ are illustrated in Figure 15 . The observed bands on the spectra are assigned based on bibliographic data [39-41] and by comparison with other similar compounds. In the high frequency region of the two spectra, the very large band between 3400 and $2800 \mathrm{~cm}^{-1}$ corresponds to the valence vibrations of the $\mathrm{N}-\mathrm{H}, \mathrm{O}-\mathrm{H}$ and $\mathrm{C}-\mathrm{H}$ groups engaged in hydrogen bonds within the crystal [42]. The bands in the region of $1700-1300 \mathrm{~cm}^{-1}$ correspond to the $\mathrm{N}-\mathrm{H}, \mathrm{N}-\mathrm{H}$ and $\mathrm{C}-\mathrm{H}$ deformation vibrations and the valence vibrations $v(C=O), v(C=C), v(C-C), v(C=N)$ and $v(C-N)[43,44]$. The bands in the range $1300-1000 \mathrm{~cm}^{-1}$ can be attributed to the valence vibrations of the $\mathrm{C}-\mathrm{C}, \mathrm{C}-\mathrm{N}$ and $\mathrm{C}-\mathrm{O}$ groups. Bands in the $1000-500 \mathrm{~cm}^{-1}$ region correspond to the out of plane bending modes of C-H, N-H, C-C and C-N groups [45].

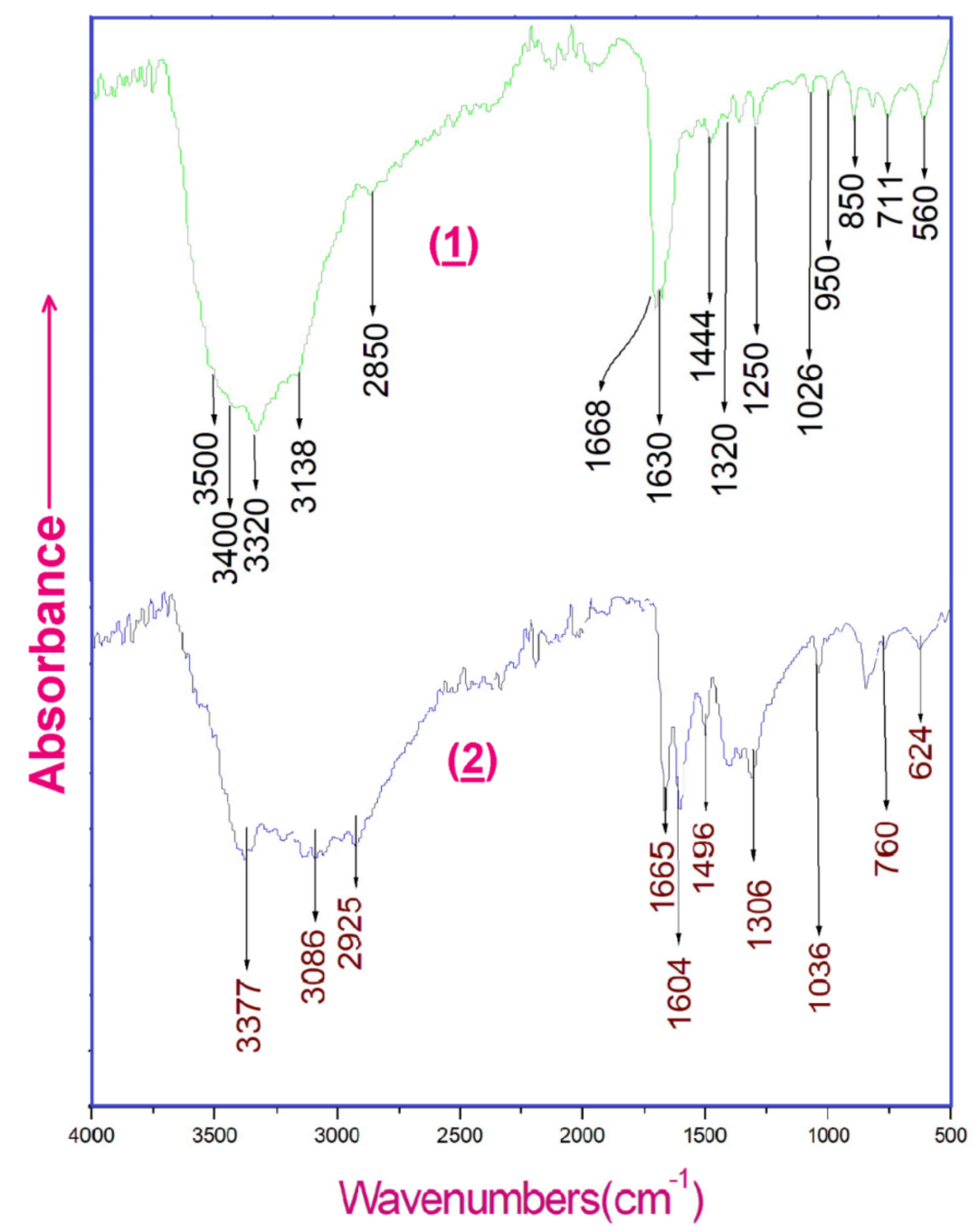

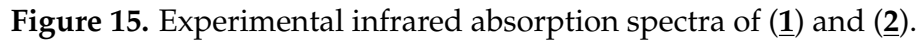

The IR spectra of compounds (1) and (2) were calculated by use of the B3LYP/6$31+G^{*}$ method. The positions of the protons were first optimized as the data of the X-ray study led to numerous imaginary frequencies, the $\mathrm{X}-\mathrm{H}$ distances being too short. The 
resulting IR spectra between 0 and $4000 \mathrm{~cm}^{-1}$ are shown on Figure S7, and are very similar to the experimental ones. A relatively good agreement is obtained between the computation and the experimental results, even if certain computed frequencies do not appear experimentally, just as certain experimental frequencies are not found, just as the intensities can be different. This is due to the fact that the calculations are made on isolated units and that the intermolecular interactions are not taken into account. This also explains why certain frequencies of the experimental/calculated spectra are not present in the diagrams of Figure S8. Thus, the precision is well-sufficient to assign the experimental frequencies and to confirm the attributions proposed above.

\subsection{Raman Scattering Spectroscopy Analysis}

The nonpolarized Raman spectra of the two compounds (1) and (2) recorded between $100-3200 \mathrm{~cm}^{-1}$ are given in Figure 16. In the high frequency Raman spectra C-H stretch ring vibrations appear at 3090-2920 $\mathrm{cm}^{-1}$. Characteristic $v(C-O)$ vibrations are also observed in the range $1100-1125 \mathrm{~cm}^{-1}$, as well as $v(=\mathrm{C}-\mathrm{H})$ in plane vibrations in the spectral range $1020-1150 \mathrm{~cm}^{-1}$. Characteristic $\mathrm{v}(\mathrm{C}=\mathrm{C})$ vibrations are also observed in the range $1500-1550 \mathrm{~cm}^{-1}$.

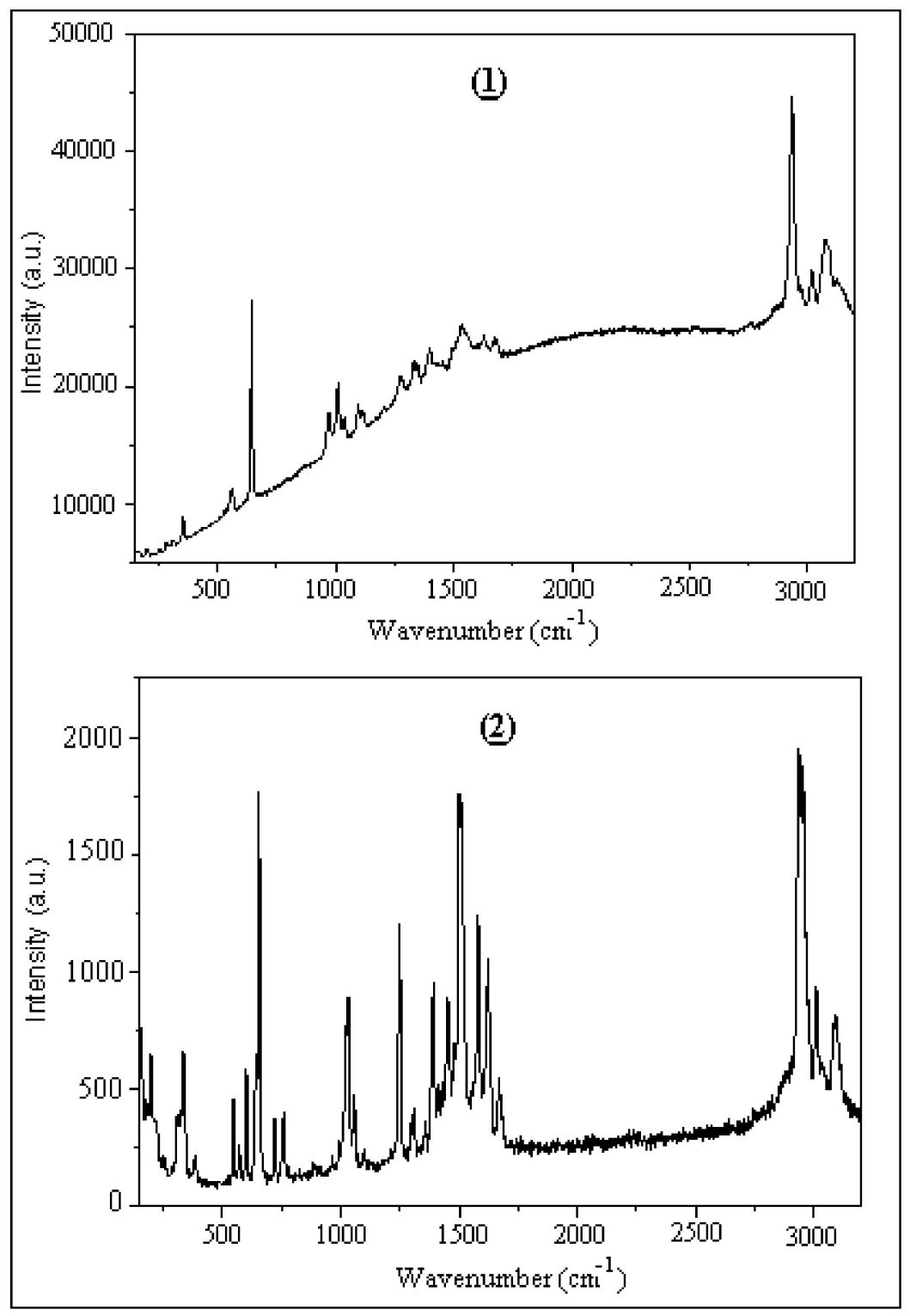

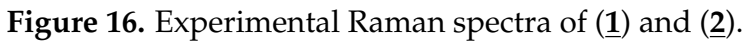


The Raman spectra were also calculated by use of the B3LYP/6-31+G* method. The calculated Raman spectra are shown on Figure S9. These results are very similar to the experimental ones. Additionally, Figure S10 presents a comparison of the experimental and theoretical results for the Raman spectra for both studied compounds. A close agreement between experimental and calculated values is mostly achieved in the fingerprint region as shown in Figure S10 ( $R=0.9968$ for (1) $), R=0.9917$ for $(\underline{2})$ ).

\subsection{Thermal Properties}

Because of the different kinds of applications of metal-organic transition complexes, especially in functional materials, the study of the thermal decomposition (or thermal stability) of complexes constitutes an important feature, since it determines the upper limit of temperature at which the complex can exist without appreciable degradation. The complexes (1) and (2) are stable in air. In order to examine the thermal stability of new complexes, TGA were carried out between room temperature and $650{ }^{\circ} \mathrm{C}$ in nitrogen atmosphere. Changes in the degradation curve can be observed on Figure 17 (Figure 17a shows the TGA curve of complexes and Figure 17b shows the curve diagram of DTG for various changes in temperature). For complexes ( $\underline{\mathbf{1}})$ and (2) the decomposition temperatures are taken as $10 \%$ and $50 \%$ weight loss $\left(T_{10}, T_{50}\right)$, respectively. For complexes $(\underline{\mathbf{1}})$ and (2) the residual masses $R$ are given in Table 10 and DSC data are given in Table 11.

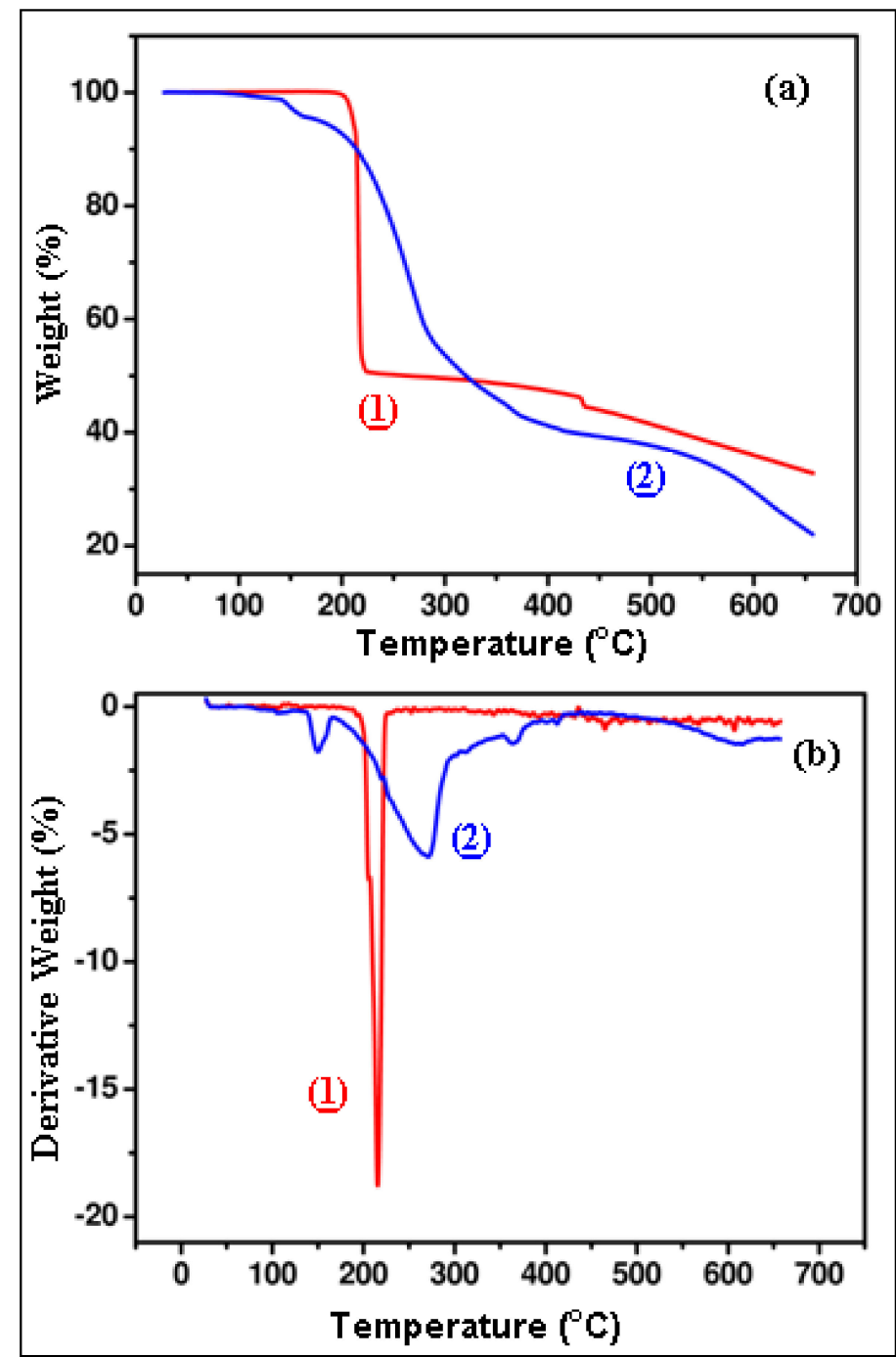

Figure 17. TGA (a) and DTG (b) curve of complexes ( $\underline{\mathbf{1}})$ and (2). 
Table 10. Results of thermal decomposition of the two compounds.

\begin{tabular}{cccc}
\hline Complex & $\boldsymbol{T}_{\mathbf{1 0}}{ }^{*}\left({ }^{\circ} \mathbf{C}\right)$ & $\boldsymbol{T}_{\mathbf{5 0}}{ }^{*}\left({ }^{\circ} \mathbf{C}\right)$ & $R *(\%)$ \\
\hline$(\underline{\mathbf{1}})$ & 214.5 & 264 & 32.7 \\
\hline$(\underline{\mathbf{2}})$ & 214.3 & 320 & 21.9 \\
\hline${ }^{*} T_{10}$ is the temperature when the weight loss of sample reaches its $10 \% ;{ }^{*} T_{50}$ is the temperature when the weight \\
loss of sample reaches its $50 \% ;{ }^{*} R$ is residual mass.
\end{tabular}

Table 11. DSC data of the two compounds.

\begin{tabular}{ccccc}
\hline Complex & Peak & Temperature Range $\left({ }^{\circ} \mathbf{C}\right)$ & Peak Temperature $\left({ }^{\circ} \mathbf{C}\right)$ & Nature of Peak \\
\hline$(\underline{\mathbf{1}})$ & 1 & $183-245$ & 212 & egzo \\
\hline \multirow{2}{*}{$(\underline{\mathbf{n}})$} & 2 & $71-128$ & 121 & endo \\
\cline { 3 - 5 } & & $135-173$ & 150 & endo \\
\hline
\end{tabular}

The results confirm the formula suggested from the analytical data. The complex (1) shows thermal stability up to $\sim 200{ }^{\circ} \mathrm{C}$ and undergoes thermal decomposition after this temperature (peak on the DTG curve at $214.5^{\circ} \mathrm{C}$ ), indicating its high thermal stability. The absence of weight loss up to $200^{\circ} \mathrm{C}$ in sample (1) indicates that there is no dehydration process in this temperature range. The dehydration process is generally found to spread over somewhat large temperature intervals [46]. The first weight loss of $50 \%$ in the temperature occurs in the range $180-220^{\circ} \mathrm{C}$, and can be interpreted as the loss of the greatest part of the complex and as its decomposition (loss of two nitrate ions, coordinated water, release of $\mathrm{H}_{2}$ and $\mathrm{H}_{2} \mathrm{O}$ gases molecules, etc.). This step is accompanied by one exothermic peak on the DSC curve at $212{ }^{\circ} \mathrm{C}$ (Table 11). However, there is no distinct peak corresponding to the process of oxidation of metallic $\mathrm{Cu}$ to $\mathrm{CuO}$. TGA peaks for the $\mathrm{Cu}$ to $\mathrm{CuO}$ process are rather weak and spread over a wide temperature range $\left(\sim 300-600^{\circ} \mathrm{C}\right)$, these observations are in close agreement with those reported in literature [45].

The TG curve of complex (2) indicates a weight loss of $4.3 \%$, which is observed in two steps, (i) a small weight loss of $\sim 1 \%$ in the range of $102-121{ }^{\circ} \mathrm{C}$ and (ii) decomposition from 136 to $165^{\circ} \mathrm{C}$ (peak on the DTG curve at $149{ }^{\circ} \mathrm{C}$ ) accompanied by an endothermic peak on the DSC curve at $150{ }^{\circ} \mathrm{C}$. This process may be attributed to the removal of the non-coordinated part of the ligand. The next step, above $\sim 200{ }^{\circ} \mathrm{C}$, corresponds to the decomposition of the coordinated part of the ligand. The latest steps at temperatures higher than $300{ }^{\circ} \mathrm{C}$ (accompanied by small peaks on the DTG curve at 364 and $413^{\circ} \mathrm{C}$ ) are attributed to the release of $\mathrm{CO}_{2}, \mathrm{H}_{2}$ and $\mathrm{HCl}$ gases and to the oxidation of $\mathrm{Co}$. The observed percentage weight losses correspond to various steps in the DSC (Table 11). The DSC result of the complex shows dehydration of water (endothermic peaks) at $121^{\circ} \mathrm{C}$ and it also exhibits a peak at $150^{\circ} \mathrm{C}$, which is the melting temperature of this compound.

\section{Conclusions}

Two new complexes $\left[\mathrm{Cu}(\text { dimpyr })_{2}\left(\mathrm{H}_{2} \mathrm{O}\right)_{2}\right]\left(\mathrm{NO}_{3}\right)_{2} \cdot 2 \mathrm{H}_{2} \mathrm{O}(\underline{\mathbf{1}})$ and (Hamdimpy $)_{2}\left[\mathrm{CoCl}_{4}\right]$. $\mathrm{H}_{2} \mathrm{O}(2)$, were prepared and characterized by various physico-chemical methods. In (1) , the $\mathrm{Cu}$ (II) cations are tetracoordinated, in a square plan fashion, by two nitrogen atoms from the organic ligand and two oxygen atoms of two coordinated water molecules. In (2), the central atom $\mathrm{Co}(\mathrm{II})$ is four-coordinated in a distorted tetrahedral fashion by four $\mathrm{Cl}^{-}$ions. The different chemical entities in the two compounds are connected together in a packing arrangement by means of several hydrogen bonds essentially of $\mathrm{O}-\mathrm{H} \ldots \mathrm{O}$ and $\mathrm{N}-\mathrm{H} \ldots \mathrm{O}$ types for the first compound and of $\mathrm{O}-\mathrm{H} \ldots \mathrm{Cl}$ and $\mathrm{N}-\mathrm{H} \ldots \mathrm{Cl}$ types for the second compound, forming three-dimensional networks. Investigation of intermolecular interactions and crystal packing via Hirshfeld surface analysis reveals that the $\mathrm{Cu} \ldots \mathrm{N}$ and $\mathrm{Cu} \ldots \mathrm{O}$ interactions for $(\underline{\mathbf{1}})$ and $\mathrm{Co} \ldots \mathrm{Cl}$ for (2) are the most attractive from an electrostatic energy point of view and are both quite enriched in the two compounds. The Hirshfeld surface analysis also shows that, for (1), H ... O intermolecular interactions 
around the complex ion represent the important percentage of the total surface $(48.5 \%)$ followed by $\mathrm{H} \ldots \mathrm{H}(34.7 \%)$, while for (2), H . . Cl intermolecular interactions represent the important percentage of the total surface (90\%). It also reveals that the driving forces in the crystal packing formation are mainly the strong hydrogen bonds. The band gap energy indicates that the two compounds are kinetically stable. DFT calculations allow the attribution of the experimental IR and Raman bands. Thermal analysis shows that the

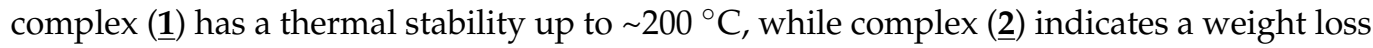
in the range of $102-121^{\circ} \mathrm{C}$.

Supplementary Materials: The following are available online at https:/ / www.mdpi.com/article/10 .3390 / cryst11080986/s1, Figure S1: Decomposed fingerprint plots of the major contacts around the nitrate group of compound (1), Figure S2: Decomposed fingerprint plots of the major contacts around the water molecule of compound ( $\underline{\mathbf{1}})$, Figure S3: Decomposed fingerprint plots of the major contacts around organic cations of compound (2), Figure S4: Decomposed fingerprint plots of the major contacts around the water molecule of compound (2), Figure S5: Energy distribution of the different orbitals of (1), Figure S6: Energy distribution of the different orbitals of the two organic cations in (2), Figure S7: Calculated infrared absorption spectrum of (1) and (2), Figure S8: Comparison between experimental and calculated IR frequencies of (1) and (2), Figure S9: Theoretical Raman spectrum of (1) and (2), Figure S10: Comparison between experimental and calculated Raman frequencies of (1) and (2).

Author Contributions: Formal Analysis, S.S., F.L. and V.F.; writing—original draft preparation, R.B., M.S. (Mirosław Szybowicz) and M.S. (Mariola Sadej); writing-review and editing, K.K.; supervision, C.B.N. All authors have read and agreed to the published version of the manuscript.

Funding: This research received no external funding.

Informed Consent Statement: Not applicable.

Data Availability Statement: Crystallographic data for the structural analysis were deposited at the Cambridge Crystallographic Data Centre, CCDC 1982375 (1) and CCDC 1982385 for (2). These data can be obtained free of charge via www.ccdc.cam.ac.uk/structures (accessed on 10 August 2021), or from the CCDC, 12 Union Road, Cambridge, CB2 1EZ, UK: fax: (+44) 01223-336-033; e-mail: deposit@ccdc.cam.ac.

Conflicts of Interest: The authors declare no conflict of interest.

\section{References}

1. Visbal, R.; Gimeno, M.C. N-heterocyclic carbene metal complexes: Photoluminescence and applications. Chem. Soc. Rev. 2014, 43, 3551-3574. [CrossRef]

2. Fabio, M.; Riccardo, P.; Claudio, P. Recent advances in acylpyrazolone metal complexes and their potential applications. Coord. Chem. Rev. 2015, 303, 1-31.

3. Joanna, M.; Małgorzata, Z.-M.; Mateusz, K.; Agnieszka, J.-W.; Patrycja, R.; Anna, A.; Barbara, B. Recent advances in coordination chemistry of metal complexes based on nitrogen heteroaromatic alcohols. Synthesis, structures and potential applications. Coord. Chem. Rev. 2016, 327, 242-270.

4. Kenji, S.; David, L.R.; Jarad, A.M.; Thomas, M.M.; Eric, D.B.; Zoey, R.H.; Tae, H.B.; Jeffrey, R.L. Carbon Dioxide Capture in Metal-Organic Frameworks. Chem. Rev. 2012, 112, 724-781.

5. Sahul, H.S.S.; Murugesan, S.; Jeyaraj, D.; Paul, R.A.J.; Arumugam, S.; Thayalaraj, C.J.; Radhakrishnan, N.A. Synthesis, characterization, DFT calculation, biological and molecular docking of $\mathrm{Cu}(\mathrm{II})$ complex of pyrimidine derived Schiff base ligand. J. Saudi Chem. Soc. 2021, 25, 101225.

6. Papazoglou, I.; Papadopoulos, A.G.; Skoulika, S.; Lafazanis, K.; Geromichalos, G.D.; Pantazaki, A.A.; Aslanidis, P. Metal-assisted desulfurization of 2-thioorotic acid: Structure, theoretical (DFT) investigations, in vitro antibacterial and cytotoxic activity and DNA degradation ability of a copper(II) complex containing in situ formed bis(4-carboxylato-6-oxo-pyrimidine-2-yl)sulfide. Polyhedron 2014, 78, 18-23.

7. Nagaraj, R.; Murugesan, S.; Jegathalaprathaban, R.; Jeyaraj, D.R. Biologically Active Cu(II), Co(II), Ni(II) and Zn(II) Complexes of Pyrimidine Derivative Schiff Base: DNA Binding, Antioxidant, Antibacterial and In Vitro Anticancer Studies. J. Fluoresc. 2017, 27, 1801-1814.

8. Nagaraj, R.; Murugesan, S.; Jeyaraj, D.R.; Vinoth, K.G.G.; Sakthivel, A.; Ramalingam, R. Bio-active mixed ligand Cu(II) and $\mathrm{Zn}$ (II) complexes of pyrimidine derivative Schiff base: DFT calculation, antimicrobial, antioxidant, DNA binding, anticancer and molecular docking studies. J. Biomol. Struct. Dyn. 2021, 39, 3012-3024. 
9. Mutlu, H.; Geiselhart, C.M.; Barner, K.C. Untapped potential for debonding on demand: The wonderful world of azo-compounds. Mater. Horiz. 2018, 5, 162-183. [CrossRef]

10. Arup, M.; David, M. Homogeneous Catalysis by Cobalt and Manganese Pincer Complexes. ACS Catal. 2018, 8, 11435-11469.

11. Heffern, M.C.; Yamamoto, N.; Holbrook, R.J.; Eckermann, A.L.; Meade, T.J. Cobalt derivatives as promising therapeutic agents. Curr. Opin. Chem. Biol. 2013, 17, 189-196. [CrossRef]

12. McKinnon, J.J.; Jayatilaka, D.; Spackman, M.A. Towards quantitative analysis of intermolecular interactions with Hirshfeld surfaces. Chem. Commun. 2007, 3814-3816. [CrossRef]

13. Maiti, A.; Svizhenko, A.; Anantram, M.P. Electronic Transport through Carbon Nanotubes: Effects of Structural Deformation and Tube Chirality. Phys. Rev. Lett. 2002, 88, 1268051. [CrossRef]

14. Burke, K. Perspective on density functional theory. J. Chem. Phys. 2012, 136, 150901-150909. [CrossRef]

15. Wu, J.Z. Density functional theory for chemical engineering: From capillarity to soft materials. AIChE J. 2006, 52, 1169-1193. [CrossRef]

16. Bernardi, F.; Bottoni, A.; Garavelli, M. Exploring Organic Chemistry with DFT: Radical, Organo-metallic, and Bio-organic Applications. Quant. Struct.-Act. Relat. 2002, 21, 128-148. [CrossRef]

17. Bally, T.; Rablen, P.R. Quantum-Chemical Simulation of H NMR Spectra. 2. Comparison of DFT-Based Procedures for Computing Proton-Proton Coupling Constants in Organic Molecules. J. Org. Chem. 2011, 76, 4818-4830. [CrossRef] [PubMed]

18. Sawant, A.B.; Nirwan, R.S. Synthesis, characterization and DFT studies of 6,8-dichloro-2-(4-chlorophenyl)-4H-chromen-4-one. Indian J. Pure Appl. Phys. 2012, 50, 308-331.

19. Rathi, P.; Khanna, R.; Jaswal, V.S. Quantum parameters based study of some heterocycles using density functional theory method: A comparative theoretical study. J. Chin. Chem. Soc. 2019, 67, 213-217. [CrossRef]

20. Sundaraganesan, N.; Elango, G.; Sebastian, S.; Subramani, P. Molecular structure, vibrational spectroscopic studies and analysis of 2-fluoro-5-methylbenzonitrile. Indian J. Pure Appl. Phys. 2009, 47, 481-490.

21. Pradeepa, S.J.; Sundaraganesan, N. Spectroscopic and molecular structure investigations of 9-vinylcarbazole by DFT and ab initio method. Spectrochim. Acta A Mol. Biomol. Spectrosc. 2015, 136, 690-699. [CrossRef]

22. Govindarasu, K.; Kavitha, E. Vibrational spectra, molecular structure, NBO, UV, NMR, first order hyperpolarizability, analysis of 4-Methoxy-4'-Nitrobiphenyl by density functional theory. Spectrochim. Acta A Mol. Biomol. Spectrosc. 2014, 122, 130-141. [CrossRef] [PubMed]

23. Otwinowski, Z.; Minor, Z. Methods in Enzymology; Carter, C.W., Sweet, R.M., Eds.; Academic Press: London, UK, 1977; Volume 276, pp. 307-326.

24. Blessing, R.H. An empirical correction for absorption anisotropy. Acta Cryst. A 1995, 51, 33-38. [CrossRef] [PubMed]

25. Altomare, A.; Burla, M.C.; Camalli, M.; Cascarano, G.L.; Giacovazzo, C.; Guagliardi, A.; Grazia, A.; Moliterni, G.; Polidori, G.; Spagna, R.J. SIR97: A new tool for crystal structure determination and refinement. J. App. Cryst. 1999, 32, 115-119. [CrossRef]

26. Sheldrick, G.M. SHELXTL-2014, Program for Crystal Structure Solution; University of Göttingen: Göttingen, Germany, 2014.

27. Farrugia, J. Win GX suite for small-molecule single-crystal crystallography. J. Appl. Crystallogr. 1999, 32, 837-838. [CrossRef]

28. Kaabi, K.; Zeller, M.; Ferretti, V.; Silva, P.P.; Nasr, C.B. Synthesis, characterization and supramolecular structure of three new $\mathrm{Cu}(\mathrm{II})$ and $\mathrm{Ni}(\mathrm{II})$ complexes with the potentially bidentate ligand 2-amino-6-methylpyrimidin-4(1H)-one (AMPO). Inorg. Chim. Acta 2012, 388, 52-59. [CrossRef]

29. Kaabi, K.; Zeller, M.; Ben Nasr, C. Synthesis, characterization and supramolecular structure of a Cu(II) complex with the potentially bidentate ligand 2-amino-6 methylpyrimidin-4- $(1 \mathrm{H})$-one: $\left[\mathrm{Cu}\left(\mathrm{C}_{5} \mathrm{H}_{7} \mathrm{~N}_{3} \mathrm{O}\right)_{4} \cdot \mathrm{Cl}_{2} \cdot 5 \mathrm{H}_{2} \mathrm{O}\right.$. Elixir Chem. Phys. 2012, 43, 6877-6882.

30. Nbili, W.; Soudani, S.; Kaabi, K.; Wojtaś, M.; Ferretti, V.; Lefebvre, F.; Jelsch, C.; Nasr, C.B. Crystal and geometry-optimized structure, Hirshfeld surface analysis and physicochemical studies of a new Co(II) complex with the ligand 2-amino-6methoxypyrimidine. J. Mol. Struct. 2017, 1146, 347-355. [CrossRef]

31. Pradhan, R.; Banik, M.; Cordes, D.B.; Slawin, A.M.; Saha, N.C. Synthesis, characterization, X-ray crystallography and DNA binding activities of $\mathrm{Co}$ (III) and $\mathrm{Cu}$ (II) complexes with a pyrimidine-based Schiff base ligand. Inorg. Chim. Acta 2016, 442, 70-80. [CrossRef]

32. Lei, Y.; Powell, D.R.; Robert, P.H. Structural variation in copper(I) complexes with pyridylmethylamide ligands: Structural analysis with a new four-coordinate geometry index, $\tau_{4}$. Dalton Trans. 2007, 955-964. [CrossRef]

33. McKinnon, J.J.; Spackman, M.A.; Mitchell, A.S. Novel tools for visualizing and exploring intermolecular interactions in molecular crystals. Acta Crystallogr. B 2004, 60, 627-668. [CrossRef]

34. Jelsch, C.; Soudani, S.; Ben Nasr, C. Likelihood of atom-atom contacts in crystal structures of halogenated organic compounds. IUCrJ 2015, 2, 327-340. [CrossRef] [PubMed]

35. Jelsch, C.; Ejsmont, K.; Huder, L. The enrichment ratio of atomic contacts in crystals, an indicator derived from the Hirshfeld surface analysis. IUCrJ 2014, 1, 119-128. [CrossRef] [PubMed]

36. Frisch, M.J.; Trucks, G.W.; Schlegel, H.B.; Scuseria, G.E.; Robb, M.A.; Cheeseman, J.R.; Scalmani, G.; Barone, V.; Mennucci, B.; Petersson, G.A.; et al. Gaussian 09, Revision A.02; Gaussian, Inc.: Wallingford, CT, USA, 2009.

37. Saikat, K.S.; Seth, B.; Tanusree, K. Crystal structure and DFT calculations of andrographiside. J. Mol. Struct. 2010, 965, 45-49.

38. Saikat, K.S.; Nitish, C.S.; Soumen, G.; Tanusree, K. Structural elucidation and electronic properties of two pyrazole derivatives: A combined X-ray, Hirshfeld surface analyses and quantum mechanical study. Chem. Phys. Lett. 2011, 506, 309-314. 
39. Calve, N.L.; Romain, F.; Limage, M.H.; Novak, A. Etude par spectroscopic spectroscopic Raman et infrarouge des verres de pseudo-spin $\mathrm{Rb}_{0.65}\left(\mathrm{NH}_{4}\right)_{0.35} \mathrm{H}_{2} \mathrm{PO}_{4}$. J. Mol. Struct. 1989, 200, 131-147. [CrossRef]

40. Ratajczak, H.J. Structural studies of some hydrogen-bonded ferroelectrics using polarized ir radiation. J. Mol. Struct. 1969, 3, 27-41. [CrossRef]

41. Navak, A. Vibrational studies of structural phase transitions in partially ordered solids. J. Mol. Struct. 1990, 217, 35-94. [CrossRef]

42. Belhouchet, M.; Bahri, M.; Savariault, J.M.; Mhiri, T. Structural and vibrational study of a new organic hydrogen sulfate. Spectrochim. Acta Part A 2005, 61, 387-393. [CrossRef] [PubMed]

43. Kaabi, K.; Rayes, A.; Ben Nasr, C.; Rzaigui, M.; Lefebvre, F. Synthesis and crystal sructure of a new dihydrogenomonophosphate (4- $\left.\mathrm{C}_{2} \mathrm{H}_{5} \mathrm{C}_{6} \mathrm{H}_{4} \mathrm{NH}_{3}\right) \mathrm{H}_{2} \mathrm{PO}_{4}$. Mat. Res. Bull. 2003, 38, 741-747. [CrossRef]

44. Oueslati, A.; Nasr, C.B.; Durif, A.; Lefebvre, F. Synthesis and characterization of a new organic dihydrogen phosphatearsenate: $\left[\mathrm{H}_{2}\left(\mathrm{C}_{4} \mathrm{H}_{10} \mathrm{~N}_{2}\right)\right]\left[\mathrm{H}_{2}(\mathrm{As}, \mathrm{P}) \mathrm{O}_{4}\right]_{2}$. Mat. Res. Bull. 2005, 40, 970-980. [CrossRef]

45. Oueslati, A.; Rayes, A.; Ben Nasr, C.; Lefebvre, F. Synthesis and characterization of 2-amino-3-methylpyridinium dihydrogenomonoarsenate. Mat. Res. Bull. 2005, 40, 1680-1689. [CrossRef]

46. Prabhumirashi, L.S.; Khoje, J.K. TGA and DTA studies on en and tmn complexes of Cu (II) chloride, nitrate, sulphate, acetate and oxalate. Thermochim. Acta 2002, 383, 109-118. [CrossRef] 